\title{
Transcriptome profiles of Quercus rubra responding to increased $\mathrm{O}_{3}$ stress
}

\author{
Nourolah Soltani ${ }^{1}$, Teo Best ${ }^{2}$, Dantria Grace ${ }^{3}$, Christen Nelms ${ }^{3}$, Ketia Shumaker ${ }^{3}$, Jeanne Romero-Severson ${ }^{4}$, \\ Daniela Moses ${ }^{5}$, Stephan Schuster ${ }^{5}$, Margaret Staton ${ }^{1^{*}}$ D, John Carlson ${ }^{2^{*}}$ and Kimberly Gwinn ${ }^{1^{*}}$
}

\begin{abstract}
Background: Climate plays an essential role in forest health, and climate change may increase forest productivity losses due to abiotic and biotic stress. Increased temperature leads to the increased formation of ozone $\left(\mathrm{O}_{3}\right)$. Ozone is formed by the interaction of sunlight, molecular oxygen and by the reactions of chemicals commonly found in industrial and automobile emissions such as nitrogen oxides and volatile organic compounds. Although it is well known that productivity of Northern red oak (Quercus rubra) (NRO), an ecologically and economically important species in the forests of eastern North America, is reduced by exposure to $\mathrm{O}_{3}$, limited information is available on its responses to exogenous stimuli at the level of gene expression.

Results: RNA sequencing yielded more than 323 million high-quality raw sequence reads. De novo assembly generated 52,662 unigenes, of which more than 42,000 sequences could be annotated through homology-based searches. A total of 4140 differential expressed genes (DEGs) were detected in response to $\mathrm{O}_{3}$ stress, as compared to their respective controls. Gene Ontology (GO) and Kyoto Encyclopedia of Genes and Genomes (KEGG) enrichment analyses of the $\mathrm{O}_{3}$-response DEGs revealed perturbation of several biological pathways including energy, lipid, amino acid, carbohydrate and terpenoid metabolism as well as plant-pathogen interaction.

Conclusion: This study provides the first reference transcriptome for NRO and initial insights into the genomic responses of $\mathrm{NRO}$ to $\mathrm{O}_{3}$. Gene expression profiling reveals altered primary and secondary metabolism of NRO seedlings, including known defense responses such as terpenoid biosynthesis.
\end{abstract}

Keywords: Northern red oak, Transcriptome, Plant-pathogen interactions, Terpenoid, Mevalonic acid, Methylerythritol phosphate

\section{Background}

Northern red oak (Quercus rubra L.) (NRO), a monocoecious species belonging to Fagaceae family, is an ecologically and economically important forest tree in North America. It is a valuable source of hardwood lumber, often used for flooring, veneer and furniture for higher grade timber and for firewood for the lower grades $[1,2]$. This hardwood species has a wide range of habitat from northern Ontario to southern Alabama and the Atlantic coast to Nebraska [3, 4]. NRO is the dominant tree species in many of the forest types across its

\footnotetext{
* Correspondence: mstaton1@utk.edu; jec16@psu.edu; kgwinn@utk.edu 'The Department of Entomology and Plant Pathology, University of Tennessee, Knoxville, TN 37996, USA

${ }^{2}$ The Department of Ecosystem Science and Management, Pennsylvania State University, University Park, PA 16802, USA

Full list of author information is available at the end of the article
}

native range, and NRO mast provides food for many native wildlife species [5-7]. NRO has a number of features that make it a good model for studies of population genetics, speciation and gene flow, including co-habitation and hybridization with several close congeners, an outcrossing mating system, and a wide geographical range [8-12].

NRO is impacted by oak population decline, a disease complex caused by a combination of biotic and abiotic stresses, originally described in the 1970's in oakdominated southeastern forests [13]. In 1999, oak decline had severely affected about 400,000 acres of forests throughout Arkansas, Missouri, and Oklahoma [14]. From 2003 to 2010, NRO decline due to relative crown dieback was estimated at $18 \%$ in southeastern forests [15]. One of the key abiotic stressors implicated in oak decline is ozone $\left(\mathrm{O}_{3}\right)$, a compound that is formed by the

(c) The Author(s). 2020 Open Access This article is distributed under the terms of the Creative Commons Attribution 4.0 International License (http://creativecommons.org/licenses/by/4.0/), which permits unrestricted use, distribution, and reproduction in any medium, provided you give appropriate credit to the original author(s) and the source, provide a link to the Creative Commons license, and indicate if changes were made. The Creative Commons Public Domain Dedication waiver (http://creativecommons.org/publicdomain/zero/1.0/) applies to the data made available in this article, unless otherwise stated. 
interaction of sunlight and molecular oxygen and by the interactions of chemicals commonly found in industrial and automobile emissions such as nitrogen oxides and volatile organic compounds. Tree physiology is altered in the presence of $\mathrm{O}_{3}$ as evidenced by elevated water use, increased respiration and transpiration, and modified carbon allocation, resulting in decreased tree vegetative growth and life span [16-20]. Forest productivity loss by exposure to $\mathrm{O}_{3}$ in the eastern USA has been estimated between 1 and 10\% [21]. Ozone stress can further damage NRO indirectly from an increase in disease and insect susceptibility in $\mathrm{O}_{3}$-exposed plants [22-24]. Several insect pests are also considered to limit growth and survival of NRO, including red oak borer Enaphalodes rufulus, Asiatic oak weevil Cyrtepistomus castaneus, carpenter worm Prionoxystus robiniae, oak timber worm Arrhenodes minutus, and pole borer Parandra brunnea [25-27]. Primary damage from these insects also increases tree susceptibility to secondary pests $[17,18,28]$.

Due to both the ecological concerns and economic impact from declining forest health, there is a critical need to develop genomic resources and molecular tools that enhance tree improvement and management programs [29]. A number of transcriptome studies on oak species have been leveraged to characterize tree response to biological and environmental stress. The most well studied stress in oak is water stress, with transcriptome studies from seedlings of Q. lobata, Q. suber, and Q. robur that have highlighted alteration of several biological functions including metabolic pathways; energy, lipid, and carbohydrate metabolisms; secondary metabolic, amino acid metabolic, and catabolic processes; sugar transport; photosynthesis; transcription factors; signal transduction; chaperone activity; and pathogenesis-related protein productions [30-32]. Other stress studies from mature oak trees included heat, cold, salinity, oxidative stress, nematode interaction, and fungal pathogenesis that have detected a similarly wide range of differentially expressed primary and secondary pathways [31-38].

Despite the importance of $\mathrm{O}_{3}$ in oak decline, there is no information on transcriptome changes in response to ozone. To fill this gap in knowledge, a transcriptome study was designed to assess gene expression differences in NRO induced by ozone exposure. In the forests of Pennsylvania, hourly ambient concentrations of $\mathrm{O}_{3}$ typically range between 30 and 80 ppb [39], with occasional occurrences greater than $100 \mathrm{ppb}$ [40]. Four ozone levels were selected for testing. Less than $10 \mathrm{ppb}$ of ozone (little or no ozone after carbon filtration of ambient air) was used as a control, with $80 \mathrm{ppb}$ and $125 \mathrm{ppb}$ as treatments to mimic observed ambient levels. These levels also relate to the U.S. Environmental Protection Agency's National Ambient Air Quality Standards (NAAQS) for ground-level ozone limits for public health and welfare, which have decreased from 1-h maximum detected levels up to $120 \mathrm{ppb}$ before 1997 , to $80 \mathrm{ppb}$ between 1997 and 2015, and to $70 \mathrm{ppb}$ since 2015 (EPA, 2015). A high stress treatment level of $225 \mathrm{ppb}$ was selected as an extreme condition. This is higher than most in situ observations, but close to the $300 \mathrm{ppb}$ level that has often been used in previous reports on ozone-stress studies to produce a strong, reproducible physiological response in model plants [41-43]. By investigating $\mathrm{O}_{3}$ stress involved in oak decline, unique molecular-level stress responses by NRO can be determined. Finally, de novo assembly of the RNA sequence data followed by functional annotation of the differentially expressed transcripts was conducted to build a catalog of transcripts in response to $\mathrm{O}_{3}$ stress for NRO.

\section{Results}

Transcriptome sequencing output, de novo assembly and transcriptome quality

More than 334 million raw reads were generated, including $639 \mathrm{Mb}$ from the 454 platform, $2.5 \mathrm{~Gb}$ from the Illumina MiSeq platform, 23.1Gb from the Illumina Hiseq 2000 platform and 42.3Gb from the Illumina HiSeq 2500 platform. RNA libraries were sequenced from a wide variety of NRO tissues to provide good coverage of the gene space $(334,073,559$ reads) (Additional file 1: Table S1). To produce a high-quality reference transcriptome, only the longer reads (originating from 454 and Illumina MiSeq) were used for assembly while the data generated from the HiSeq 2500 platform were used exclusively for differential gene expression analysis.

After trimming low-quality bases, adapter removal, transcriptome assembly, and removal of redundant sequences, 52,662 putative transcripts with an average length of $778 \mathrm{bp}$ and N50 length of $1244 \mathrm{bp}$ were generated (Additional file 2: Fig. S1). Transdecoder predicted an open reading frame (ORF) in 38,610 (73\%) of the putative transcripts. In order to verify completeness of the transcriptome assembly, putative transcripts were $>$ compared with the Embryophyta database of orthologs $(n=1440)$ by BUSCO; $988(68.6 \%)$ of the single-copy orthologs have a complete match within the oak transcriptome sequences. Another 166 (11.5\%) of the singlecopy orthologs were found as fragments, and 286 (19.9\%) were missing from the oak transcriptome assembly.

While no reference genome is available for Q. rubra nor any other species from the red oak clade (subgenus Quercus sect. Lobatae) [44], three reference genomes from oak species in other clades are available: Q. lobata (Quercus sect. Quercus) [45], Q. robur (Quercus sect. Quercus) [46], and Q. suber (Cerris sect. Cerris) [47]. To assess sequence divergence between this NRO assembly 
and gene models from the reference genomes, read mapping through Conditional Reciprocal Best BLAST was performed. The proportion of NRO putative transcripts with a match to a gene model in the three oak species genomes was $68.2 \%$ to Q. lobata, $82.4 \%$ to Q. robur, and $66 \%$ to $Q$. suber, revealing no clear pattern of gene conservation associated with taxonomic relationship. It will be interesting for subsequent phylogenomics studies to determine if the variation in NRO putative transcripts mapping frequency among the species is different among sections of the genus Quercus reflects evolutionary distances versus quality and completeness of gene annotations among reference genomes.

\section{Sequence annotation}

Homology-based functional assignments were obtained for a total of 37,535 and 37,880 putative transcripts from NCBI and IPS databases, respectively. Integration of results from both databases yielded annotation for 42,703 $(81 \%)$ of the putative transcripts. The most common protein matches from NCBI BLAST originated from other woody plant species: Juglans regia, Ziziphus jujuba, Theobroma cacao, Prunus persica, and Vitis vinifera. Although an E-value cut-off of 1e-5 was used for the BLAST alignments, the majority of the sequence hits were strongly supported by much lower E-values (Additional file 2: Figure S1). Gene Ontology (GO) terms were assigned to a total of 29,528 (69.1\%) annotated putative transcripts. To give a broad overview of annotations, GO term assignments were re-mapped to secondtier GO terms, yielding 70 total terms (Additional file 3: Figure S2), which included: 21,623 putative transcripts that were assigned to terms in the biological process ontology (BP), 20,073 putative transcripts that were assigned to terms in the cellular component ontology (CC), and 24,819 putative transcripts that were assigned to terms in the molecular function (MF) group. The most abundant GO terms for each category were classified as metabolic processes $(16,696)$ and cellular processes $(16,125)$ for $\mathrm{BP}$, cell $(14,036)$ and cell part $(13,972)$ for CC, and binding $(16,103)$ and catalytic activity $(15,065)$ for MF categories. Based on the full set of retrieved GO terms, a total of 10,026 Enzyme Commission (EC) numbers were assigned to annotated putative transcripts, which were utilized to obtain Kyoto Encyclopedia of Genes and Genomes (KEGG) pathway assignments. Categories of retrieved EC numbers included hydrolases (3766), transferases (3267), oxidoreductases (1928), lyases (424), isomerases (346), and ligases (295).

\section{Analysis of DEGs}

The high depth RNA sequencing data was used to profile alterations in gene expression caused by $\mathrm{O}_{3}$ stress.
Significant DEGs between treatment and control tissue samples were defined at an adjusted $p$-value cut-off of 0.05 and $\mid \log 2$ (fold change) $\mid>1$.

Two-year-old NRO seedlings were exposed to four levels of $\mathrm{O}_{3}$ (control, $80 \mathrm{ppb}, 125 \mathrm{ppb}, 225 \mathrm{ppb}$ ), and leaf tissue samples from four biological replicates were taken at three time points $(7 \mathrm{~h}, 14 \mathrm{~d}, 28 \mathrm{~d})$. The leaves at the control and $80 \mathrm{ppb}$ levels appeared similar, with no visual injury. Injury was noted at the 125 and $225 \mathrm{ppb}$ exposures. Leaves had the dark red interveinal stippling that is characteristic of moderate $\mathrm{O}_{3}$ damage of hardwoods (Additional file 4: Figure S3).

Across all elevated $\mathrm{O}_{3}$ treatment levels, 4136 DEGs were detected with 2142 transcripts upregulated and 1994 downregulated (Table 1). The number of DEGs identified varied from none found at $7 \mathrm{~h}(\mathrm{hr})$ of $80 \mathrm{ppb}$ $\mathrm{O}_{3}$, to a maximum of 3120 DEGs after 28 days of 225 $\mathrm{ppb} \mathrm{O}_{3}$ exposure (Additional file 5: Table S2). The number of DEGs increased both with greater levels of $\mathrm{O}_{3}$ and with longer exposure times. The majority of DEGs were found to be unique to each time point. However, a few DEGs were shared among multiple analyses or time points (Fig. 1). DEGs for each $\mathrm{O}_{3}$ concentration regardless of time were determined via comparison of $\mathrm{O}_{3}$ treated and control samples across all time points using filtering options stated above. While at $80 \mathrm{ppb}$ no DEGs was detected, a total of 33 (32 up-, 1 downregulated) and 70 (52 up-, 18 downregulated) DEGs were identified at $125 \mathrm{ppb}$ and $225 \mathrm{ppb}$, respectively (Additional file 5: Table S2).

\section{GO enrichment categories among DEGs}

GO term enrichment analysis was conducted separately for each treatment to characterize biological functions represented in DEGs. For downregulated DEGs in $\mathrm{O}_{3}$ experiments, significantly enriched $\mathrm{GO}$ terms were found only at the treatment level of $225 \mathrm{ppb}$. Enriched GO terms from up-regulated DEGs were identified across all three $\mathrm{O}_{3}$ treatments (Figs. 2 and 3). Most down-regulated DEGs, 10 in total, are involved in photosynthesis, and several significant up-regulated DEGs were related to alterations in respiration and photosynthesis (Additional file 6: Figure S4). As photosynthesis activities were found for both upregulated and downregulated genes, we examined the specific genes more closely. For upregulated genes in photosynthesis (at 125 $\mathrm{ppb}$ ), the genes included two isoforms of photosystem II cytochrome b559 and one gene related to chloroplastic ATP synthase CF0, which both relate to transmembrane activities. In contrast, the downregulated genes at 225 $\mathrm{ppb}$ are involved in core chloroplastic activities and organelles (chlorophyll, light receptor, thylakoid lumen, and degradation of damaged proteins in the chloroplast). These genes had specific functional annotations of 
Table 1 Number of significant DEGs in response to $\mathrm{O}_{3}$ treatment over time

\begin{tabular}{|c|c|c|c|c|c|c|}
\hline \multirow{2}{*}{$\begin{array}{l}\text { Time } \\
\text { Treatment }\end{array}$} & \multicolumn{2}{|l|}{$7 \mathrm{~h}$} & \multicolumn{2}{|l|}{$14 d$} & \multicolumn{2}{|l|}{$28 d$} \\
\hline & Up regulated ${ }^{a}$ & Down regulated $^{a}$ & Up regulated & Down regulated & Up regulated & Down regulated \\
\hline $80 \mathrm{ppb}$ & 0 & 0 & 25 & 1 & 61 & 8 \\
\hline $125 \mathrm{ppb}$ & 32 & 1 & 32 & 2 & 248 & 92 \\
\hline $225 \mathrm{ppb}$ & 50 & 18 & 250 & 197 & 1444 & 1675 \\
\hline
\end{tabular}

${ }^{a}$ DEGs regulation patterns and their respective total counts

chlorophyll a-b binding, photosystem I reaction center, photosystem II core complex, LOW PSII ACCUMULATION, psbP domain-containing, and protease Dolike chloroplastic. For the $\mathrm{O}_{3}$ concentration-specific DEGs determined regardless of timepoint, enrichment analysis of GO terms for upregulated and downregulated DEGs at $125 \mathrm{ppb}$ were not significant. However, top enriched biological terms for upregulated and downregulated DEGs at $225 \mathrm{ppb}$ were cysteine metabolism and steroid metabolism, respectively (Additional file 6: Figure S4).

Regulation patterns of GO terms are shown. Bp: biological process; cc: cellular component; mf: molecular function.

\section{KEGG pathway enrichment analysis of DEGs}

KEGG pathway enrichment tests were conducted with the upregulated and downregulated DEGs identified in the GO enrichment analysis (above). The number of perturbed pathways illustrated an impressive diversity of biochemical functions, which increased in scope both with time of exposure and $\mathrm{O}_{3}$ concentration (Fig. 4; Additional file 7: Table S3). The three most highly enriched upregulated KEGG pathways were oxidative phosphorylation, metabolic pathways, and photosynthesis, while the most downregulated KEGG pathways were plant-pathogen interactions, RNA transport, and diterpenoid biosynthesis. For the $\mathrm{O}_{3}$ concentrationspecific DEGs, KEGG pathways analysis of upregulated DEGs at $125 \mathrm{ppb}$ detected photosynthesis as the top enriched biological pathway (Additional file 7: Table S3) with involvement of three DEGs, however, downregulated DEGs were not enriched for photosynthesis activities. Enrichment analysis of upregulated DEGs at 225 ppb detected top significant KEGG pathways as sulfur metabolism (Additional file 7: Table S3), while downregulated DEGs were not significant.

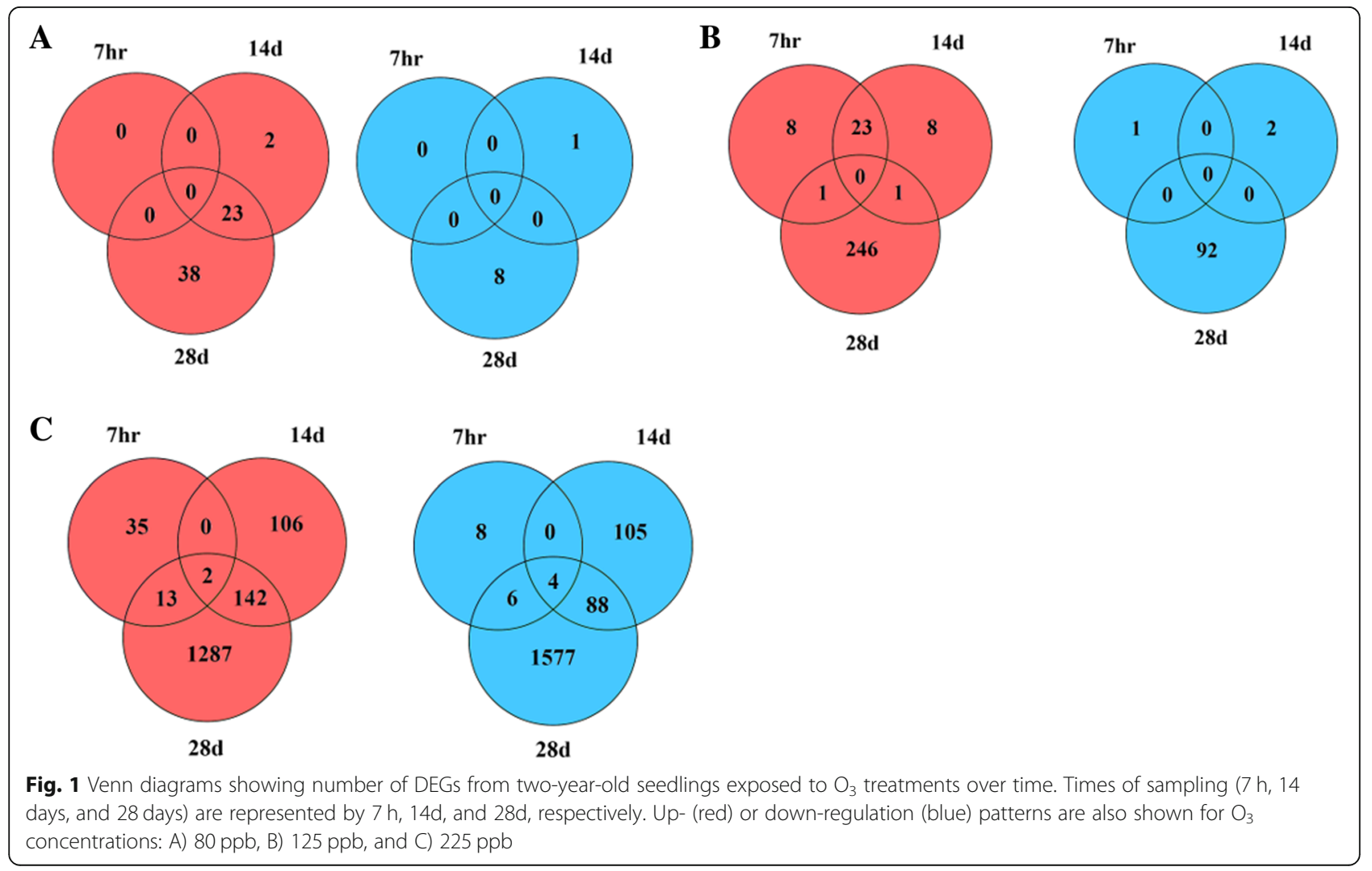




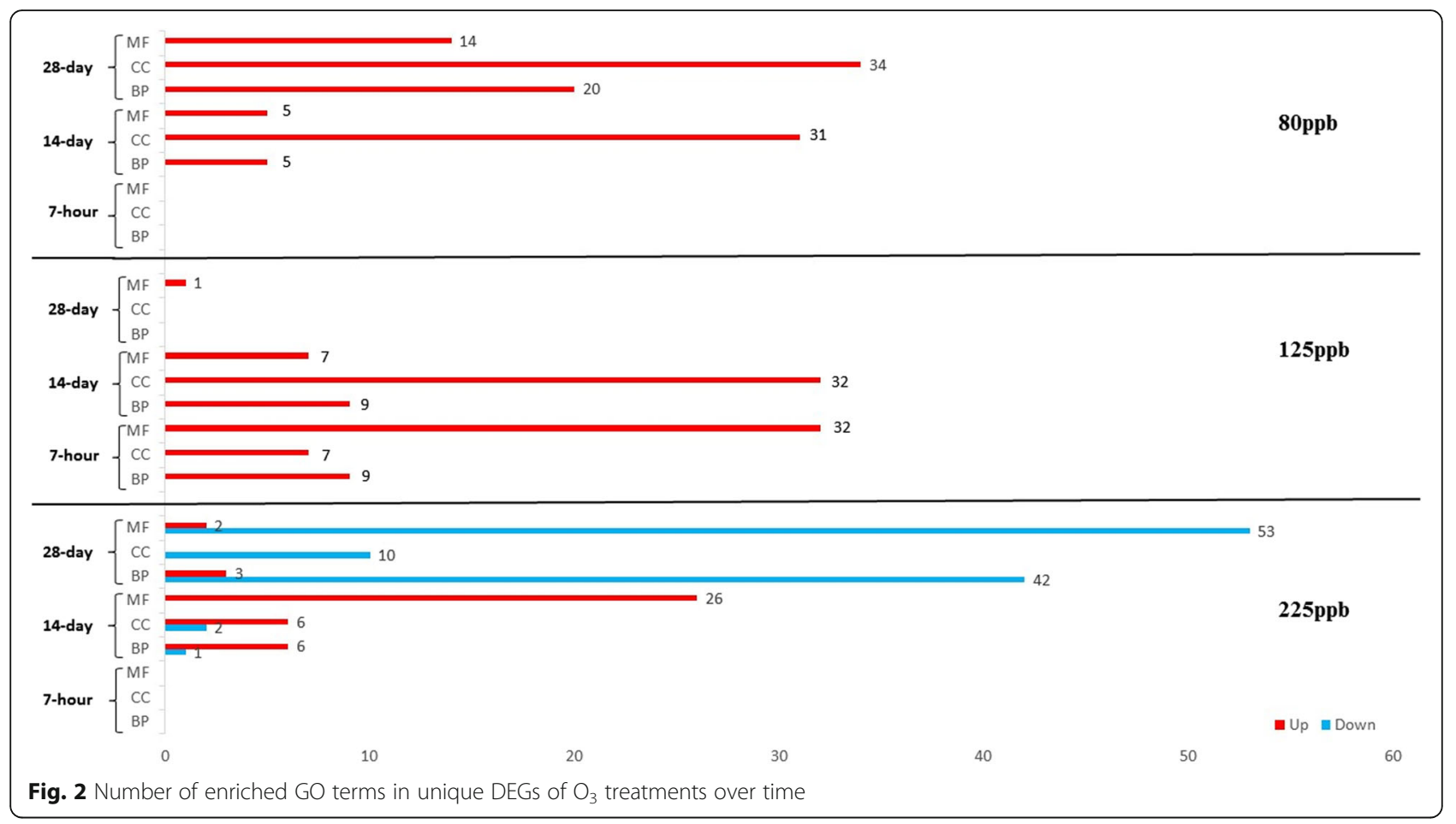

\section{Time-series analysis of DEGs}

Characterization of temporal dynamics of DEGs following $\mathrm{O}_{3}$ induction using Short Time-series Expression Miner software (STEM) software [48] was performed by clustering DEGs based on the similarity of their temporal expression patterns. STEM analysis clustered 1388 DEGs in seven significant profiles, of which most DEGs grouped in the profiles representing downregulation pattern over time (Fig. 5a; Additional file 8: Table S4). Functional annotation of DEGs associated with significant clusters detected enriched GO terms and KEGG pathways only in profiles 0,12 , and 13 . For DEGs associated to profile 13 with the upregulation pattern over time, the top two significant biological functions were cell part and metabolic pathways (Fig. 5b). The top two enriched biological pathways of clustered DEGs in both profiles of 0 and 12 with the downregulation pattern over time were organic substance metabolism and RNA transport (Fig. 5c-d).

\section{Detection of co-expressed genes upon ozone stress}

To identify co-regulation of gene clusters during ozone treatments, weighted correlation network analysis (WGCNA) was carried out using all samples. The total of 44,078 genes were clustered in 57 modules (Fig. 6), with a range of 121 (ME56) to 12,492 (ME0) genes per module. The modules represent subsets of genes with highly correlated patterns of expression. For each module, a module eigengene (ME) has been calculated to represent the first principal component of the module.
The eigengene can be interpreted as an "average" expression value representing all the genes in the module. Module-factor relationships were calculated to assess correlation of gene clusters to experimental factors. This provides a p-value indicating how well modules are correlated with each factor in the experiment. ME39 with 260 genes was the most correlated cluster responding to $80 \mathrm{ppb}$ of $\mathrm{O}_{3}$. The most significant biological KEGG pathways enriched in ME39 were sesquiterpenoid and triterpenoid biosynthesis, pyruvate metabolism, and biosynthesis of secondary metabolites (Additional file 9: Table S5). ME51 was the most correlated module responding to $125 \mathrm{ppb}$ of $\mathrm{O}_{3}$. It contained 187 genes, of which the most represented biological functions were protein processing in endoplasmic reticulum, defense response, and response to stimulus (Additional file 9: Table S5). ME5 was the most correlated module of genes responding to $225 \mathrm{ppb}$ of $\mathrm{O}_{3}$ that comprised of 1039 genes, of which the most significant biological KEGG pathways were metabolic pathways, carbon metabolism, and biosynthesis of secondary metabolites (Additional file 9: Table S5). Factor comparison in the co-expression module-factor relationship (Fig. 6) indicated that two modules, ME5 and ME53, were differentially co-expressed in response to $225 \mathrm{ppb}$ of $\mathrm{O}_{3}$ (versus control). Aside from ME5 described above, ME53 contained 6248 genes with the most significant KEGG pathways involved in spliceosome, metabolic pathways, and protein processing in endoplasmic reticulum (Additional file 9: Table S5). 


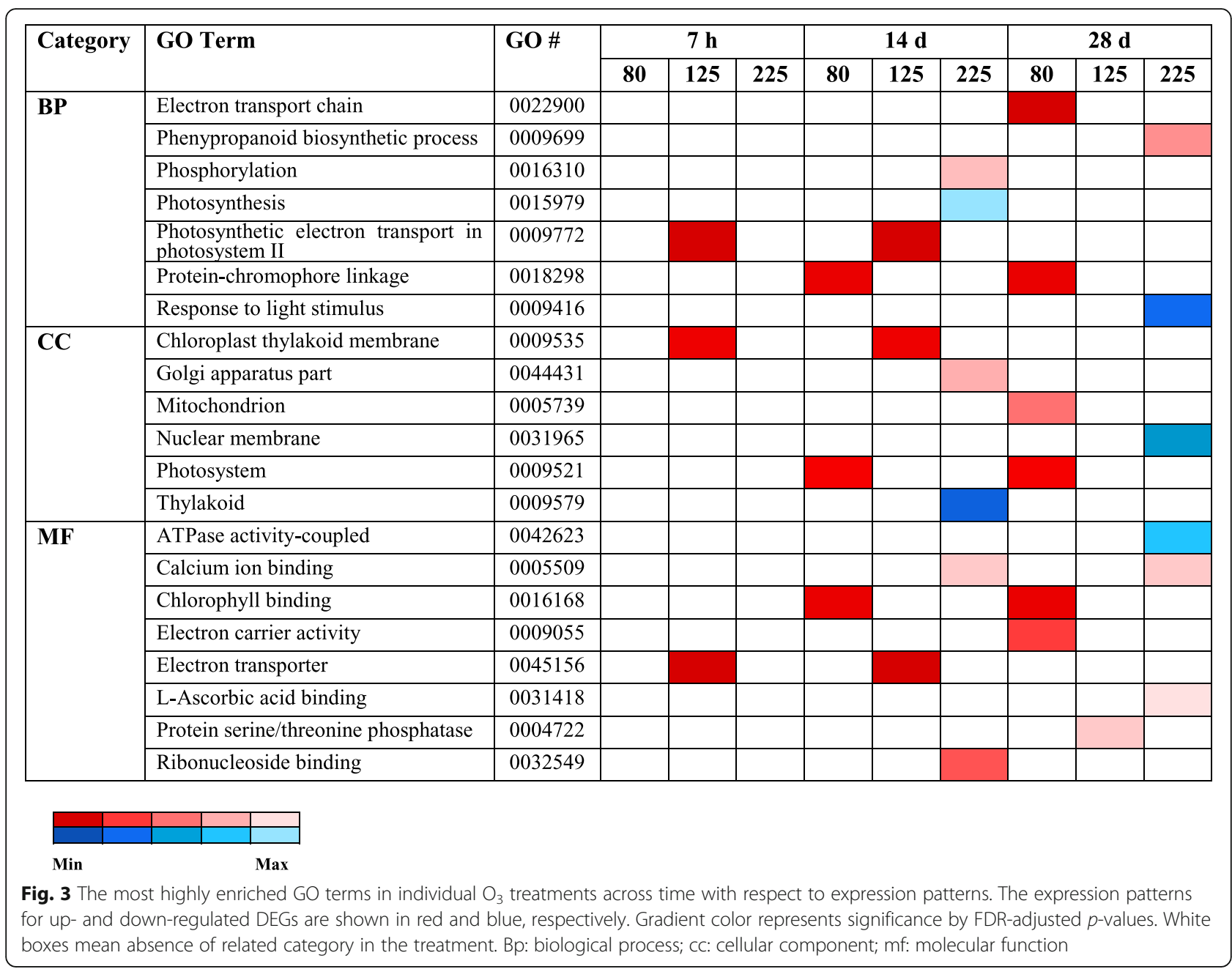

Significant enriched DEGs in plant-pathogen interaction pathway

While KEGG pathway mapping and GO term enrichment analysis are powerful methods to determine the overall biological and metabolic processes for a set of genes, both analyses are limited by the number of genes that have been accurately annotated. With de novo assembled transcriptomes and sequence similarity-based functional annotation, direct examination of the gene lists can reveal additional important pathways. In $\mathrm{O}_{3}$-exposed samples, a total of 14 upregulated and one downregulated stress response DEGs were found that also had an annotation to the plantpathogen interaction pathway from KEGG (Table 2).

\section{Identification of DEGs involved in terpenoid biosynthesis pathway}

The DEGs induced in $\mathrm{O}_{3}$ stress were involved in several pathways related to terpenoids, including biosynthesis of secondary metabolites, terpenoid backbones, and diterpenoids. Ozone stress resulted in three terpenoid biosynthesis related DEGs (Table 3). The number of downregulated
DEGs was higher than upregulated DEGs. Perturbed genes covered a set of enzymatic activities including synthesis, oxidation, and reduction.

\section{Discussion}

Although several transcriptome studies have previously identified candidate genes and pathways involved in response to multiple biotic and abiotic stressors in various oak species [30-32, 35, 36], knowledge at the genomic level of the effect of increased ground-level $\mathrm{O}_{3}$ toxicity to $\mathrm{NRO}$ is lacking. In this transcriptome study, NRO leaf tissues were exposed to four levels of $\mathrm{O}_{3}$ treatments in a time-series ( $7 \mathrm{~h}, 14$ day, 28 day) experiment, in order to reveal candidate genes and gene products key to NRO response to this abiotic stress.

\section{Transcriptome assembly and annotation of putative transcripts}

The de novo transcriptome assembly generated a total of 52,662 putative transcripts as a resource to further genomic research in NRO and related oak species. The total average length and N50 contig length are comparable to 


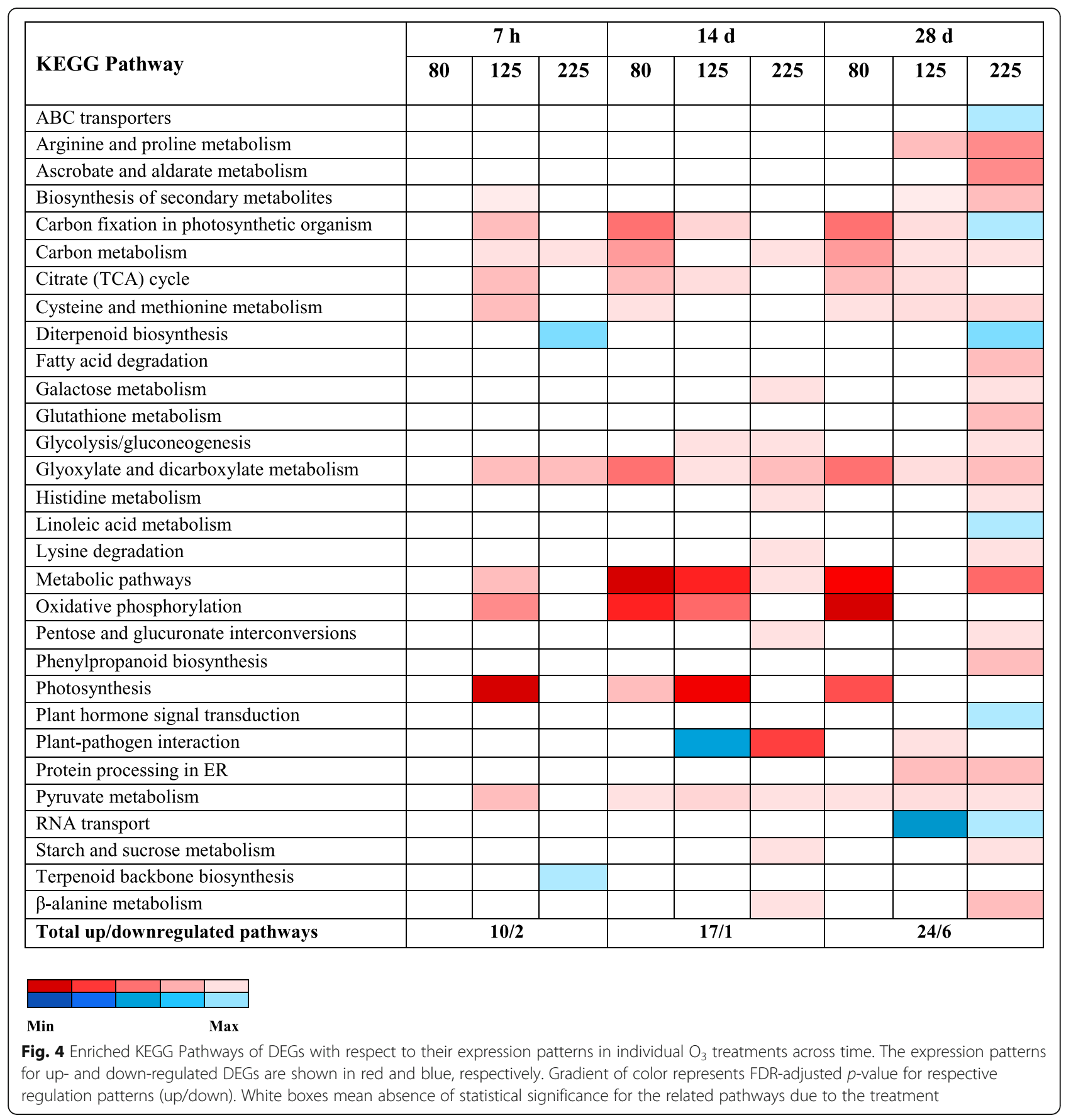

the reference transcriptomes developed to date for other forest trees [49-52]. More than $80 \%$ of the NRO putative transcripts could be functionally annotated, and the GO term assignments indicated that a broad set of fundamental metabolic processes and biological pathways were included. This distribution of GO terms is consistent in scope with previous reference de novo transcriptome studies, including oak [30,36,37] and non-oak species [53-55]. Thus, the transcriptome reported here provides a good reference for NRO studies. However, further improvements in gene space coverage and structural and functional annotations could be achieved through assembly of a reference genome, complete with full length gene models, for Q. rubra.

Impacts of ozone exposure to NRO leaves among ozone concentrations, time-specific ozone concentrations, and time-series exposures

In this study, gene expression patterns in the NRO seedlings varied by both time and concentration of $\mathrm{O}_{3}$ stress 
(A)

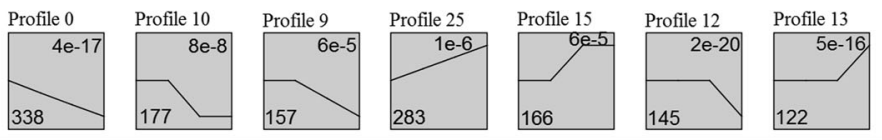

(B)

Profile 13
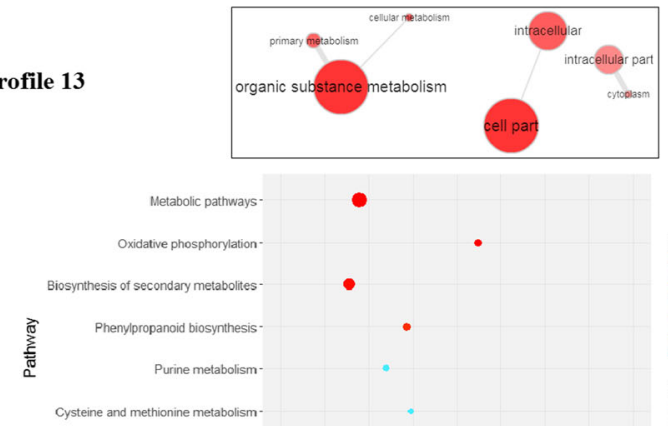

Gutathione metabolism -
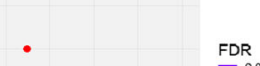

Nicotinale and nicotnamide metabolisn

$0.00 \quad 0.05$ Enrichment_score $0.15 \quad 0.20$

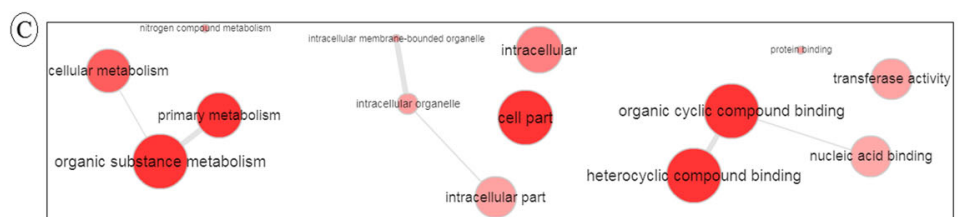

Profile 12

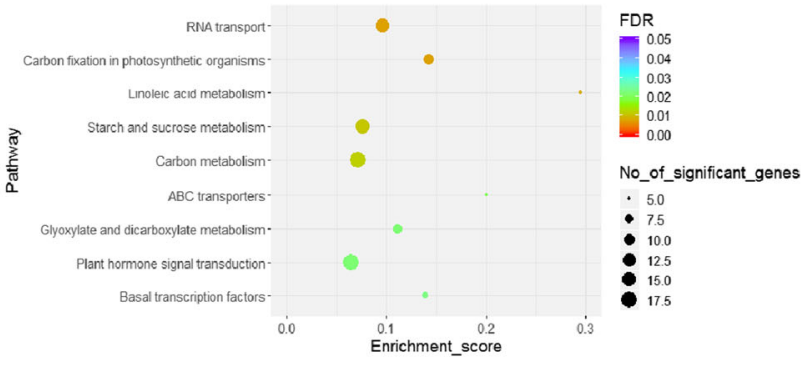

(D)

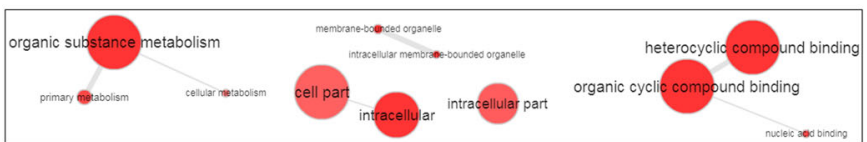

Profile 0

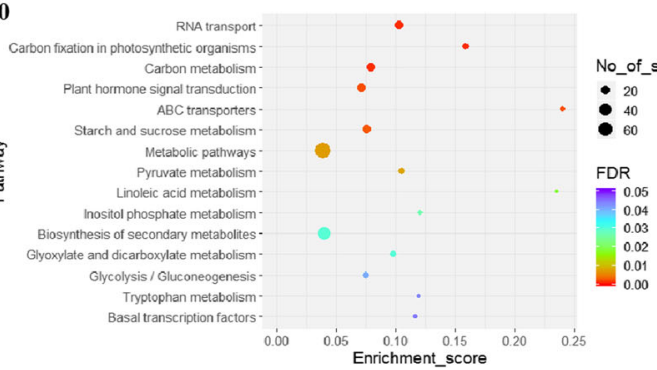

Fig. 5 Time-series and enrichment analysis of DEGs associated with ozone-exposed samples versus their control. A) Overall temporal expression profiles of DEGs with statistically significant clusters. On top of each box, profile number is represented. Left to right of X-axis in each profile represents over time pattern. Top right of individual profile is the profile enrichment $p$-value, and lower left is the number of DEGs assigned to each model profile. B-D) Enriched GO terms and KEGG pathways of DEGs in profile numbers 13, 12, and 0 . For the GO terms, the larger the size of circle, the higher the frequency; and darker the red color, lower the $p$-value. For the KEGG pathways, enrichment score is the number of significant genes divided by background genes of respective pathway; FDR is the false discovery rate corrected $p$-value 


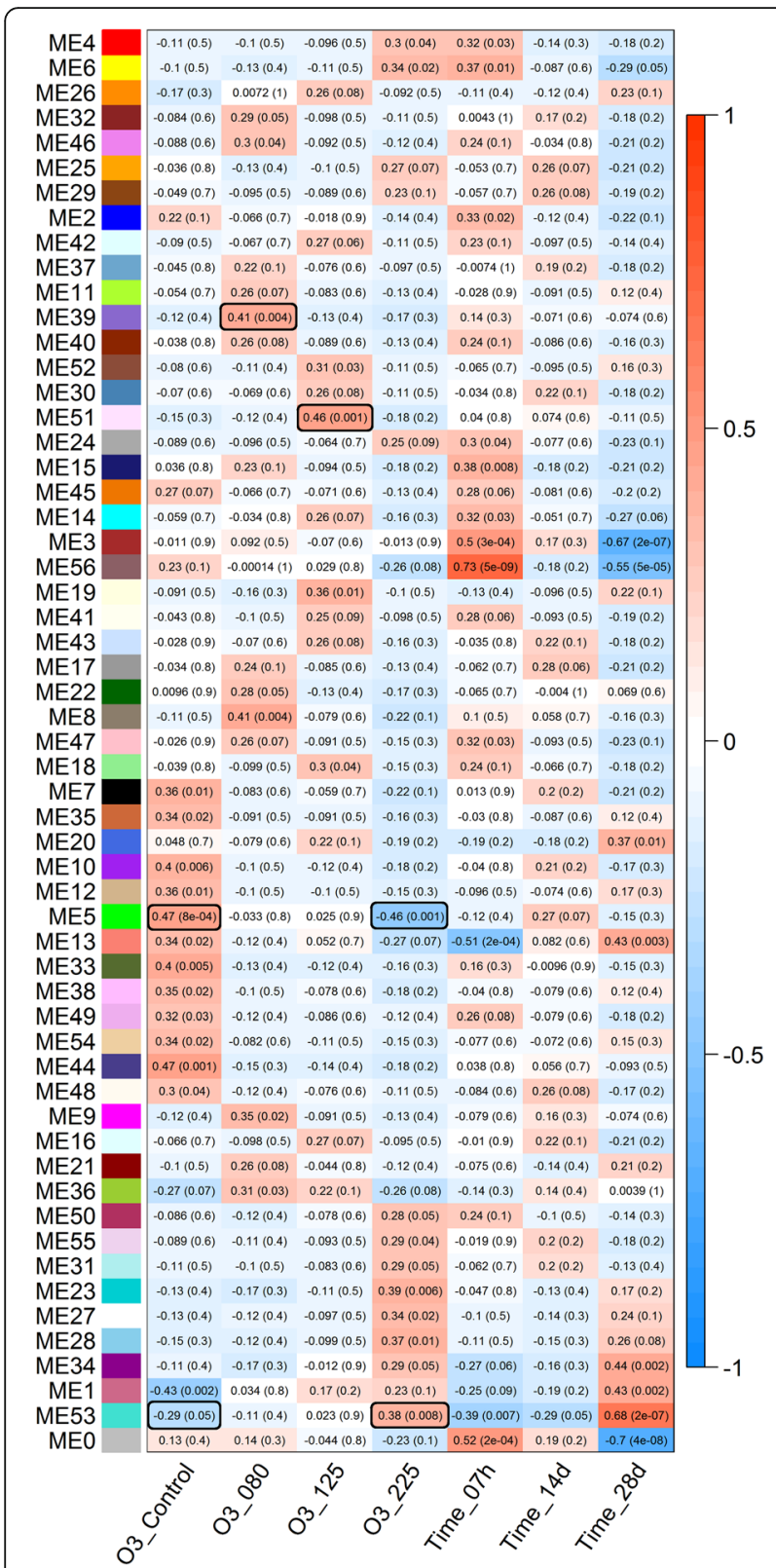

Fig. 6 Module-factor relationship summarizing co-expressed gene clusters in respective module eigengene (ME) in northern red oak in response to ozone exposure. Individual ME with respective color is indicated on the $Y$ axis, and ozone treatments and exposure time points are shown on the $X$ axis. In each box correlation coefficient and its $p$-value in parenthesis indicating correlation significance of respective treatment/time per detected ME. The color gradient shows expression profile of respective treatment/time in each ME. Highly correlated modules responding to ozone concentrations of 80,125 , and 225 plus differential expression profile of $225 \mathrm{ppb}$ versus control are highlighted in black

treatments. At the lowest treatment level of $80 \mathrm{ppb}$, gene expression did not differ from the control at the $7 \mathrm{~h}$ time point. In contrast, at higher $\mathrm{O}_{3}$ concentrations, gene expression was actively responding to the treatments even at first time point of $7 \mathrm{~h}$. Overall, the number of differentially expressed genes increased as both a function of time and increasing $\mathrm{O}_{3}$ levels.

Perturbation of carbon metabolism genes was observed among 125 and $225 \mathrm{ppb} \mathrm{O}_{3}$-exposed tissues, as well as temporal expression pattern analysis. In addition, altered metabolic pathways during the short-term exposure $(7 \mathrm{~h})$ at the two higher $\mathrm{O}_{3}$ levels of $125 \mathrm{ppb}$ and 225 $\mathrm{ppb}$ and time-series analysis were carbohydrate, amino acid, terpenoid biosynthesis and energy production. Genes involved in these biological pathways were also co-expressed in response to $\mathrm{O}_{3}$ as they were assigned to co-expression modules, ME5 and ME53. Biological pathways have also been perturbed in the seedlings of Q. lobata upon drought stress [32] and seedlings of Q. suber during ectomycorrhizal interaction [56]. Higher expression levels of genes participating in the glycolysis and citrate (TCA) cycles during $\mathrm{O}_{3}$ exposure could be expected to result in increased ATP synthesis, as documented previously in multiple plant species [57-59]. Consistent with previous research [60-62], energy production and carbohydrate fixation pathway gene activities were also affected in our study. In the long term, however, increased carbon use can lead to damaged photosynthetic machinery, a phenomenon that ultimately results in reduced ecological and economic productivity [63, 64], as evidenced by early leaf senescence in trees due to ozone stress in nature $[65,66]$. Biosynthesis of several defensive secondary metabolites including terpenoids is modulated in plants in response to environmental changes, pathogens and herbivores [67-69] as well as oaks in response to environmental changes and soil-borne microbes [32, 56]. Terpenoids are a class of bioactive compounds with antimicrobial, anti-herbivore, and insecticidal functions, which can be involved in attenuation and suppression of $\mathrm{O}_{3}$ induced oxidative-stress damages [70-72]. Five different types of terpenoids, mono-, di-, tri-, tetra-, and sesquiterpenoid, are biosynthesized through sequential condensation of isoprene unit blocks resulting from cytosolic mevalonic acid (MVA) or plastidal methylerythritol phosphate (MEP) pathways. Sesqui- and triterpenoids are produced through the MVA pathway, whereas mono-, di- and tetraterpenoids are biosynthesized through the MEP pathway $[55,67]$. In this study, perturbation of terpenoid biosynthesis due to $\mathrm{O}_{3}$ exposure was a result of changes in expression levels of three enzymes; enzymes involved in the MVA pathway were downregulated while those in the MEP were upregulated (Table 3; Fig. 7). Modulation of these pathways upon $\mathrm{O}_{3}$ exposure in NRO is consistent with reports for oxidative stress studies in other woody plants [71, 73].

The stress treatments of NRO seedlings for medium length of $\mathrm{O}_{3}$ exposure (14d) resulted in alterations in 
Table 2 DEGs involved in plant-pathogen interaction pathway

\begin{tabular}{|c|c|c|c|c|c|c|}
\hline $\begin{array}{l}\text { Ozone treatments with respective } \\
\text { regulation pattern }\end{array}$ & Putative transcripts id & $M E^{b}$ & Annotation & $\mid \operatorname{LogFC}^{a}$ & KEGG entry & Length (bp) \\
\hline $125 \mathrm{ppb}$ at 14 day-down & comp19736_c0_seq3 & MEO & Disease resistance RPM1 & 6.26 & K13457 & 682 \\
\hline \multirow[t]{7}{*}{$125 \mathrm{ppb}$ at 28 day-up } & comp21410_c0_seq1 & ME1 & Heat shock cognate 80 & 1.43 & K04079 & 1281 \\
\hline & comp31660_c0_seq2 & ME1 & Enhanced disease susceptibility 1 & 2.43 & K18875 & 2272 \\
\hline & comp31660_c0_seq1 & ME1 & Enhanced disease susceptibility 1-like & 2.55 & K18875 & 946 \\
\hline & comp26463_c0_seq2 & ME1 & Calcium-dependent kinase 10 & 2.46 & K13412 & 2130 \\
\hline & comp28434_c0_seq1 & ME53 & Calcium-binding CML23 & 2.03 & K13448 & 661 \\
\hline & comp18561_c0_seq1 & ME1 & Lipase_3 domain-containing & 3.52 & K18875 & 367 \\
\hline & comp94592_c0_seq1 & ME53 & Calcium-binding CML45 & 3.27 & K13448 & 786 \\
\hline \multirow[t]{7}{*}{$225 \mathrm{ppb}$ at 14 day-up } & comp31273_c0_seq7 & ME51 & $\begin{array}{l}\text { Disease resistance At1g12280 (LRR and } \\
\text { NB-ARC domains) }\end{array}$ & 3.61 & K13459 & 845 \\
\hline & comp18481_c0_seq1 & ME53 & Calcium-dependent kinase & 5.63 & $\mathrm{~K} 13412$ & 596 \\
\hline & comp9320_c0_seq1 & MEO & 26-like & 3.56 & K13412 & 833 \\
\hline & comp21573_c0_seq1 & MEO & Calcium-dependent kinase 26 -like & 1.43 & K04079 & 888 \\
\hline & comp31660_c0_seq5 & ME5 & Heat shock cognate 80 -like & 1.49 & K18875 & 1932 \\
\hline & comp23142_c0_seq3 & ME31 & Enhanced disease susceptibility & 1.25 & K20536 & 1335 \\
\hline & comp31028_c0_seq1 & ME5 & $\begin{array}{l}\text { Mitogen-activated kinase } 3 \\
\text { Respiratory burst oxidase homolog A }\end{array}$ & 2.04 & K13447 & 3505 \\
\hline
\end{tabular}

\footnotetext{
${ }^{a}$ Variation in logFC indicates the amount of log-based changes of gene expression level in the treatment compared with respective control sample

${ }^{\mathrm{b}} \mathrm{ME}$ refers to the module number from the gene coexpression network analysis
}

GO terms that predict alterations in protein levels of exposed plants at all $\mathrm{O}_{3}$ levels; co-expressed genes were clustered in modules ME5, ME51, and ME53. These terms included protein complex, protein-chromophore linkage, cysteine and methionine metabolism, histidine metabolism, and lysine degradation. Furthermore, overexpression of sulfur metabolism genes at $225 \mathrm{ppb}_{3}$ exposure, and cysteine and methionine metabolism in either over-time analysis or $\mathrm{O}_{3}$ exposure of $225 \mathrm{ppb}$ was observed. Modulation of amino acid metabolism upon exposure of oak seedlings to water stress [32] and ectomycorrhizal contact [56] might imply this pathway as a common stress responsive mechanism during exposure to abiotic stimuli, which is in agreement with results of previous studies related to ozone-exposed plants [60, 62]. In plants, reactive oxygen species (ROS) can react with thiol and sulfur-containing groups of cysteine and methionine [74] and lead to conformational changes in histidine and lysine amino acids, which impairs protein function and increases susceptibility to proteolytic reactions [75]. Furthermore, ROS trigger protein oxidation, a phenomenon which often causes irreversible covalent alteration of the protein structure [74]. The expression of plant-pathogen interaction pathway and related genes are reported to be altered in response to biotic and abiotic stimuli in plants $[76,77]$ such as $Q$. robur seedlings exposed to waterlogging [31]. Furthermore, activation of defense pathways can lead to priming of unexposed tissues for faster gene expression responses to stress and may lead to defense reactions such as hypersensitive response (HR). In our study, co-expression of plantpathogen interaction pathway/defense response was observed in all $\mathrm{O}_{3}$ treatments, where these defensive responses were assigned to modules ME5, ME39, ME51, and ME53. Among these pathways and responses, upregulation of an "enhanced disease susceptibility" gene

Table 3 DEGs involved in terpenoid biosynthesis pathway

\begin{tabular}{|c|c|c|c|c|c|c|c|}
\hline $\begin{array}{l}\text { Treatments that induced differential } \\
\text { expression }\end{array}$ & $\begin{array}{l}\text { Putative transcripts } \\
\text { id }\end{array}$ & $M E^{a}$ & Annotation & $\begin{array}{l}\text { Role in terpenoid } \\
\text { pathway }\end{array}$ & $|\mathrm{LogFC}|$ & $\begin{array}{l}\text { KEGG } \\
\text { entry }\end{array}$ & $\begin{array}{l}\text { Length } \\
\text { (bp) }\end{array}$ \\
\hline $\begin{array}{l}\text { Shared } 7 \text { h\&28d at } 225 \mathrm{ppb} \text {, } \\
\text { Downregulated }\end{array}$ & $\begin{array}{l}\text { comp29400_c1_ } \\
\text { seq4 }\end{array}$ & ME53 & $\beta$-Amyrin 11-oxidase-like & Diterpenoid & 1.83 & K04123 & 289 \\
\hline $225 \mathrm{ppb}$ at $7 \mathrm{~h}$-Downregulated & $\begin{array}{l}\text { comp28709_c0_ } \\
\text { seq1 }\end{array}$ & ME2 & $\begin{array}{l}\text { 3-Hydroxy-3-methylglutaryl- } \\
\text { coenzyme A reductase }\end{array}$ & $\begin{array}{l}\text { Terpenoid } \\
\text { backbone }\end{array}$ & 1.99 & K00021 & 1630 \\
\hline $225 \mathrm{ppb}$ at 28 day-Upregulated & $\begin{array}{l}\text { comp313540_c0_ } \\
\text { seq1 }\end{array}$ & ME53 & $\begin{array}{l}\text { Geranylgeranyl pyrophosphate } \\
\text { synthase }\end{array}$ & $\begin{array}{l}\text { Terpenoid } \\
\text { backbone }\end{array}$ & 5.99 & K13789 & 227 \\
\hline
\end{tabular}

${ }^{\mathrm{a}} \mathrm{ME}$ refers to the module number from the gene coexpression network analysis 




and downregulation of "disease resistance RPM1" gene could potentially alter HR and programmed cell death, which would ultimately result in cell vulnerability and impairment. In this study, induction of calcium-dependent putative transcripts, may indicate increased levels of defense signal-transduction systemically to distal plant tissues [78]. The amino acid glutamate plays a key role in long distance signaling, priming defense responses through systemic acquired resistance pathways [78]. In past studies, exposure to $\mathrm{O}_{3}$ was reported to result in upregulation of plant-pathogen interaction pathways such as pathogenesis-related proteins $1-4$ and small heat shock proteins; our study differed from previous reports in that pathogenesis-related proteins were not differentially expressed in the NRO seedlings [79-81].

Photosynthesis and ATP production pathway genes were observed to be consistently upregulated after long term (28d) exposure to $\mathrm{O}_{3}$ and among $125 \mathrm{ppb}$-exposed tissues, as it has been documented in several studies
[60-62, 82]. However, evidence of altered carbon fixation through 1,5-bisphosphate carboxylase (Rubisco) gene expression was inconsistent among exposure times and $\mathrm{O}_{3}$ levels. However, co-expression analysis showed that photosynthesis- and ATP production-related genes were both clustered in the modules ME5 and ME53. In addition to latter modules, ME39 and ME51 also contained ATP production-associated genes. After long term $\mathrm{O}_{3}$ exposure (28d), downregulation of Rubisco at the highest $\mathrm{O}_{3}$ concentration was observed. Several explanations for downregulation of Rubisco have been proposed including inhibited transcription, mRNA degradation, and reduction of stomatal conductance in response to $\mathrm{O}_{3}[83,84]$. Modulation of stomatal conductance alters the uptake of atmospheric $\mathrm{CO}_{2}$ to intercellular spaces, which ultimately affects carbon fixation and sugar deposition [85]. The indication of decreased carbon fixation from altered gene expression patterns in the treated NRO seedlings is consistent with previous 
studies related to oaks and other woody trees [85-87]. In our study, differential gene expression results suggested that photosynthesis was upregulated, rather than being suppressed. Although photosynthesis is reported to be decreased during elevated $\mathrm{O}_{3}$ in some plant systems [88-91] and oak species (Q. lobata and Q. suber) exposed to drought [30,32], it is typically increased in younger tissues in response to stress [92-94]. However, photosynthetic rates of tree seedlings have been reported to be less sensitive to $\mathrm{O}_{3}$ than mature trees [92-94]. For plants to recover from damage to photosynthetic compartments, seedlings need to assimilate the sugar and starch that are essential for growth. This is generally accomplished through carbon shifts allocation to the roots. However, $\mathrm{O}_{3}$ and other photosynthetic poisons can alter shifts carbon in favor of the shoot, which along with increased photosynthetic rates can result in early leaf senescence and decreased seedling growth [95]. In our study, after 28 days of exposure to high $\mathrm{O}_{3}$ levels, many genes associated with the plant defense cascades were upregulated. For example, ROS can perturb the plantpathogen interaction pathway, which in turn activates HR through either effector-trigger immunity (ETI) or pathogen-associated molecular pattern-triggered immunity (PTI) that circumvent $\mathrm{O}_{3}$ induced damages. Overexpression of two isoforms of "enhanced disease susceptibility 1" (EDS1)", as well as induction of heatshock protein (HSP) and calcium-dependent/binding genes in the $\mathrm{O}_{3}$-treated NRO seedlings might thus be attributable to stimulation of HR by either ETI or PTI. Higher levels of ROS in cells ultimately leads to programmed cell death [96]. Therefore, consistent with past studies [60,62], increased expression of HSP and amino acid glutathione, an important anti-oxidant, plus other ROS scavengers in plant tissues, as we observed, may provide detoxification methods that diminish $\mathrm{O}_{3}$ induced damages $[16,57,97]$.

DEGs that were observed to be upregulated in the $\mathrm{O}_{3}$ experiment included transcription factors such as WRKY and other genes known to be involved in host defense responses, including HSP and thaumatin-like protein genes. Heat-stress transcription factors play an important role in regulation of expression of genes such as the HSP protein gene which responds to stresses and promotes plant defense reactions. Thaumatin-like proteins are PR proteins that are induced in response to pathogen/pest attack and are involved in plant resistance responses [98]. In other oak seedling studies, another closely-related HSP family (HSP20) [30, 32] and several transcription factors such as WRKY [30, 32, 56] and those regulating HSPs [56] were differentially expressed during drought and fungal stresses. Modulation of multiple transcription factors including WRKY upon ozone exposure were also documented in several other plants
$[60,62]$. On the other hand, the observed downregulation of $\mathrm{ABC}$ transporter (annotated as $\mathrm{ABC}$ transporter family G member 11 [ABCG 11]), LRR receptor-like DEGs and terpenoid pathway genes after ozone exposure of the NRO plants suggests some active defense mechanism may be disturbed by this stress, potentially increasing susceptibility to pathogens and pests. Perhaps such downregulation of gene expression also represents reduction in resource use for tissues already proceeding to apoptosis and senescence. Modulation of $\mathrm{ABC}$ transporter and LRR receptor-like genes during $\mathrm{O}_{3}$ stress is consistent with oak seedling studies associated with fungal and drought stresses [31, 32, 56]. In Arabidopsis, ABCG 11 mutants lose water maintenance and plant defense functionality through disturbance of cuticle membrane lipid transfer [99]. LRR receptor-like genes regulate diverse developmental and defense related processes including non-host-specific defense reactions induced pathogen infection [100].

While the use of four independently sequenced biological replicates in this study lends statistical confidence to the results, the limited red oak genetic background is a limitation. The genes and pathways reported here need to be further queried, preferably through independent repeats of this experiment using additional red oak genotypes and ozone levels. This could yield information about how well these responses are conserved across red oak populations.

\section{Conclusion}

In this paper we reported the development of a reference transcriptome for NRO developed from deep sequencing, and assembly, of RNAs from wide variety of NRO developmental stages. The reference transcriptome assembly consists of 52,662 unigenes, of which more than 42,000 transcripts were annotated by sequence homology and by gene ontology to a broad array of functional classifications. Over 4100 differentially expressed genes were detected in response to a time course of $\mathrm{O}_{3}$ stress at 3 levels, versus untreated controls. Although much has been learned through previous ecological and physiological studies on the effects of ozone-stress in NRO and other forest trees, to the best of our knowledge this is the first study of genome-wide gene expression responses of NRO plants to ozone stress. Exposure to elevated ozone levels led in both cases to activation of a cascade of defense gene expression, including altered carbohydrate, amino acid, lipid, and terpenoid biosynthesis as well as altered photosynthesis and ATP production pathway genes. The ozone toxicity is example of oxidative stresses, during which ROS are produced, impair lipid and protein functions and increase susceptibility to proteolytic reactions. Enhanced glutathione as suggested by upregulated gene expression (temporal and 
concentration-dependent) in the leaves indicated activation of antioxidant-detoxification pathways in response to the oxidative stresses imparted by ozone treatments. Prolonged exposure of oak trees to this external stimulus could increase susceptibility to secondary pests and pathogens, contributing to oak population decline. Further characterization of the candidate genes from this study should be pursued as opportunities to enhance resistance against biotic and abiotic stressors through oak breeding and reforestation programs. Additional genomic resources, such as a reference genome for Q. rubra, would further support research on NRO adaptation and resistance to different stresses.

\section{Methods}

\section{Plant materials and ozone treatments}

Tissue samples were collected from two adjacent mature NRO trees on the campus of Purdue University, West Lafayette, Indiana (accessions SM1 and SM2) [101]. The tissues sampled included dormant twigs, immature twigs, developing acorns, emerging leaves, catkins, emerging leaf buds, late growth stage (season) damaged leaves, late growth stage undamaged leaves, late growth stage damaged twigs, and late growth stage undamaged twigs. All tissues were flash frozen in liquid nitrogen immediately after collection, and then kept frozen in either in liquid nitrogen or on dry ice during transport to the lab for storage at $-80^{\circ} \mathrm{C}$. These materials were sequenced using MiSeq and 454 instruments and used exclusively for transcriptome assembly.

\section{Ozone stress}

Two ozone exposure experiments were performed. For the initial experiment, open pollinated acorns collected from SM1 were germinated and grown for two years in the greenhouse under normal ambient conditions. In the summer of 2011, 24 two-year old seedlings were randomly assigned among four continuous stirred tank reactor (CSTR) chambers [cylindrical in shape, with dimensions of $107 \mathrm{~cm}$ (diameter) $\times 122 \mathrm{~cm}$ (height)] [102], with six seedlings transferred into each chamber. Each CSTR chamber was equipped with an external overhead light source (400 watt lamps $[\sim 15 \mathrm{klx}])$ producing light quality similar to natural sunlight. The seedlings were acclimated to the chambers for 2 weeks at normal ambient growing conditions, after which the $\mathrm{O}_{3}$ concentrations were adjusted to a different level in each chamber, at $<10$ ppb (control), $150 \mathrm{ppb}, 225 \mathrm{ppb}$, and $300 \mathrm{ppb}$. The specific ozone levels were accomplished by an airintake scrubbing system consisting of activated charcoal filtration unit that lowered ambient air ozone levels in the greenhouse to $<10 \mathrm{ppb}$ hourly average. Ozone was then added to each CSRT chamber via a controllable micro-metering system with concentrations monitored with a TECO Model $49 \mathrm{O}_{3}$ analyzer and data logger/computer recording system in each chamber [103]. The augmented $\mathrm{O}_{3}$ was delivered in square-wave fashion for 7 day/wk., eight hours a day $(0900 \mathrm{~h}$ to $1559 \mathrm{~h})$ for 28 days, mimicking diurnal ozone fluctuation. In treatments greater than ambient, cumulative ozone exposure ranged from 864 to 1728 $\mathrm{ppb}$ h for $7 \mathrm{~h}$ treatments, from 13,992 to $25,152 \mathrm{ppb} h$ for 14 day exposures, and from 28,008 to $50,328 \mathrm{ppb} \mathrm{h}$ for 28 day exposures. The metric $\mathrm{ppb} h$ was calculated as $(\mathrm{ppb} \times 8 \mathrm{~h} \times \#$ days). During non-fumigation hours, seedlings remained within the chambers with the doors open to the charcoal filtered air and environmental conditions within the greenhouse. Three to four leaves were collected from different areas in the canopy (lower, mid and upper) at each of the three time points $(7 \mathrm{~h}, 14$ days, 28 days) from all biological replicates. Leaves were flash frozen in liquid nitrogen immediately after collection, and then kept frozen in either in liquid nitrogen or on dry ice during transport to the lab for storage at $-80{ }^{\circ} \mathrm{C}$. For each replicate, the leaves were pooled prior to RNA extraction. After isolation, equal amounts of RNA from the replicates were pooled by treatment level prior to sequencing by a 454 instrument for use in transcriptome assembly.

A second $\mathrm{O}_{3}$ exposure experiment was performed with 48 two-year open-pollinated seedlings grown from acorn collected from accession SM1. In this experiment, four seedlings were used as biological replicates in each of four CSTR chambers, treated at $\mathrm{O}_{3}$ concentrations adjusted to: < $10 \mathrm{ppb}$ (control), $80 \mathrm{ppb}, 125 \mathrm{ppb}$, and 225 ppb. Less than $10 \mathrm{ppb}$ of ozone (little or no ozone after carbon filtration of ambient air) was used as a control, with $80 \mathrm{ppb}$ and $125 \mathrm{ppb}$ as treatments to mimic observed ambient levels. These levels also relate to the U.S. Environmental Protection Agency's NAAQS for groundlevel ozone limits for public health and welfare, which have decreased from 1-h maximum detected levels up to $120 \mathrm{ppb}$ before 1997, to $80 \mathrm{ppb}$ between 1997 and 2015, and to $70 \mathrm{ppb}$ since 2015 (EPA, 2015). A high stress treatment level of $225 \mathrm{ppb}$ was selected as an extreme condition. This is higher than most in situ observations, but close to the $300 \mathrm{ppb}$ level that has often been used in previous reports on ozone-stress studies to produce a strong, reproducible physiological response in model plants [41-43]. Leaf samples were collected and tracked individually from each of the biological replicates at three time points ( $7 \mathrm{~h}, 14$ days, 28 days) for the 4 ozone treatment levels. Leaf samples were collected and processed as described above. RNAs were isolated and replicates sequenced separately on Illumina instruments to generate data for use in differential expression analysis. 
RNA purification, library construction and transcriptome profiling

The frozen tissue samples were powdered by grinding in liquid nitrogen and transferred back to $-80^{\circ} \mathrm{C}$ freezer conditions if not immediately extracted for RNA. Total RNA was extracted from the powdered tissue samples following a modified CTAB isolation method [104] with lithium chloride precipitation. RNA quality was assessed by capillary electrophoresis using the Agilent Bioanalyzer 2100 (Agilent technologies).

Libraries for 454 instrument sequencing were constructed as per supplier's instructions for the Titanium reagents with modifications as described as in [105]. The libraries were sequenced at Pennsylvania State University using an FLX+454 DNA sequencer (Roche). For the initial $\mathrm{O}_{3}$ experiment, equal amounts of RNA from individual biological replicates were pooled into a single sample for each ozone treatment level. Two additional 454 libraries were constructed from the parent tree samples one from a pooled set of equal amounts of RNA from above ground tissue samples and one from a pooled set of below ground tissue samples.

For the second $\mathrm{O}_{3}$ stress experiment, biological replicates were independently barcoded for sequencing. Illumina TruSeq libraries were prepared for each of the replicate RNA samples, following manufacturer protocols, then sequenced on an Illumina HiSeq 2500 instrument at Pennsylvania State University.

All RNA-Seq data are available in the NCBI Sequence Read Archive database under BioProject accession number PRJNA273270.

\section{RNA-seq preprocessing, de novo assembly and quality assessment}

The quality of generated RNA-Seq data was inspected by FastQC software [106] and low-quality reads (mean Phred score $<20$ ) were cleaned by Trimmomatic using default parameters [107]. Only reads originating from the 454 instrument or the MiSeq instrument were included in the assembly, due to their longer read lengths. Trimmed reads were assembled by Trinity (version downloaded on 2012-10-05) [108]. The assembly was further refined by cd-hit-est v4.6.1 with a sequence identity threshold of 0.95 to collapse isoforms and reduce assembly redundancy [109].

All transcript names begin with "Quercus_rubra 120313_" to indicate transcriptome origin and version. This part of the transcript name has been removed from the text for brevity. For example, transcript "Quercus_ rubra_120313_comp102049_c0_seq1" is referred to in the text as "comp102049_c0_seq1".

The quality of the transcript assembly was checked by Transrate version 1.0.3 [110]. Transrate was also used to compare transcripts to available oak reference genomes by read mapping through Conditional Reciprocal Best BLAST with default cut-off value of $1 \mathrm{e}-5$. Candidate coding regions within assembled transcripts were predicted by Transdecoder software version 5.1.0 [111]. Transcriptome completeness was checked by Benchmarking Universal Single-Copy Orthologs (BUSCO) version 3 based on the plant ortholog database (embryophyta_odb9) [112]. Reads were mapped back to the transcriptome assembly with bowtie2 v2.2.1 using the -sensitive parameter.

\section{Functional annotation, pathway identification and gene expression analysis}

Gene ontology (GO) functional classification of the transcriptome assembly was carried out using the Blast2GO program [113] based on the NCBI non-redundant (nr) protein sequences by fast-BLASTX [114] with an Evalue cut-off of 1e-5 as well as EBML-EBI InterProScan (IPS) database. Gene ontology [115] terms were obtained for each putative transcript from both BLAST and IPS outputs. WEGO [116] was used to examine the GO terms among the annotated putative transcripts. The EC numbers were retrieved through GO-EnzymeCode Mapping feature of Blast2GO software.

\section{Identification, annotation and enrichment analyses of differentially expressed genes}

For differential gene expression of ozone exposure, only data from the second ozone experiment was used for analysis; this experiment had individually barcoded replicates and high depth of reads generated by the HiSeq instrument. To obtain raw read counts for each putative transcript per library HTSeq version 0.6.1 [117] was used. The raw count matrix were provided to the edgeR version 3.6 bioconductor package [118] to distinguish differentially expressed genes (DEGs) between treatment and control groups. Briefly, normalization by the trimmed mean of M-values (TMM) method was calculated to adjust count reads. Normalized factors, the counts per million (CPM), were used in common, trended and tag-wise dispersion analyses by Cox-Reid profile-adjusted likelihood (CR) method. Finally, to determine significant DEGs negative binomial general linearized model (GLM) likelihood ratio was tested based on the model (treatment"time), where treatment was ozone concentrations, and time was time-points for each treated sample. Genes were considered significantly differentially expressed based on adjusted $p$-value $<0.05$ [119] and $\mid \log 2$ (fold change) $\mid>1$. Consensus DEGs detected by edgeR package were visualized by Venny version 2.1 [120] and their results were used in further annotation and enrichment analyses.

GO enrichment analysis of DEGs was carried out by agriGO v2 [121] with the significant DEGs of each 
model as the foreground dataset and all putative transcripts as the background reference. The statistical parameters used for identification of overrepresented GO terms were Fisher's exact test, adjusted for multiple testing by FDR with a cut-off value at the significance level of 0.05. Statistical enrichment of DEGs within constructed pathways based on Kyoto Encyclopedia of Genes and Genomes (KEGG) database was tested by KEGG Orthology-Based Annotation System (KOBAS) program [122].

\section{Time-series analysis of differentially expressed genes}

The analysis of DEGs over time was analyzed by STEM using the $\log$ fold-change of DEGs $\left(\mathrm{O}_{3}\right.$-treated versus control) among the three time points, where all samples from the same time point were combined. The parameters in STEM were adjusted as follows: maximum unit change in model profiles between time points set to 1; maximum output profiles number set to 50 . The clustered profiles with $p$-value $<0.05$ were defined as significant profiles. The enriched clusters were further analyzed by KOBAS to determine their GO terms and KEGG pathways, of which biological function of profiles with adjusted $\mathrm{p}$-value $<0.05$ were considered significant.

\section{Weighted gene co-expression network analysis}

TMM-normalized gene expression values were used in an R package, WGCNA [123], to identify modules containing co-expressed genes. After removal of genes with zero normalized counts, one-step network construction and module detection were performed using unsigned block-wise-module comprised of at least 100 genes per module. A consensus gene expression profile for each module was represented by the module eigengene that was calculated through first principal component analysis. The module-factor relationship was obtained through Pearson correlation coefficient. The top hub gene, i.e. the gene with the highest connectivity, for each module was identified with the WGCNA package.

\section{Supplementary information}

Supplementary information accompanies this paper at https://doi.org/10. 1186/s12864-020-6549-5.

Additional File 1: Table S1. Number of reads and bases produced for each RNA library used in assembly.

Additional File 2: Figure S1. E-value distribution of northern red oak sequence hits obtained in BLAST analysis against $\mathrm{nr}$ database, and metrics of transcriptome assembly obtained by Transrate.

Additional File 3: Figure S2. Second-tier GO terms assigned to northern red oak transcripts.

Additional File 4: Figure S3. Image of northern red oak leaf after exposure to $125 \mathrm{ppb}$ ozone for 28 days. Symptoms of toxicity in NRO leaves are visible as inter-vein red stippling and small lesions.
Additional File 5: Table S2. Unique and common DEGs in ozone stress.

Additional File 6: Figure S4. Enriched $G O$ terms for ozone stress. Additional File 7: Table S3. Enriched KEGG pathways of ozone stress. Additional File 8: Table S4. Profiles of clustered DGEs over time-series analysis by STEM.

Additional File 9: Table S5. Coexpression network data, including module membership for all genes, top hub gene for each module, and enriched GO and KEG terms for the modules most strongly correlated to experimental factors

\section{Abbreviations}

ABCG 11: ABC transporter family $G$ member 11; BP: Biological process; CC: Cellular component; DEG: Differential expressed gene; EC: Enzyme commission; EDS1: Enhanced disease susceptibility 1; ETI: Effector-trigger immunity; FDR: False discovery rate; GGDP: Geranylgeranyl pyrophosphate; GO: Gene ontology; HMG-CoA: 3-Hydroxy-3-methylglutaryl-coenzyme A; HR: Hypersensitive response; HSP: Heat shock protein; IPP: Isopentenyl pyrophosphate; IPS: Interproscan; KEGG: Kyoto encyclopedia of genes and genomes; MEP: Methylerythritol phosphate; MF: Molecular function; MVA: Mevalonic acid; NRO: Northern red oak; $\mathrm{O}_{3}$ : ozone; ORF: Open reading frame; PPB: Part per billion; PR: Pathogenesis-related protein; PTI: Pathogenassociated molecular pattern-triggered immunity; ROS: Reactive oxygen species; TCA: Citrate cycle

\section{Acknowledgements}

The authors thank Lynn Tomsho and Nicole Zembower for expert technical assistance with the 454 and Illumina sequencing and clerical assistance. The authors also thank the Bionformatics Resource Center of the University of Tennessee, Knoxville for providing Blast2Go software, and Purdue University for providing Northern red oak resources.

\section{Authors' contributions}

NS analyzed and interpreted the data and prepared the manuscript. TB performed ozone chamber experiments and RNA extractions. DG and CN assisted with ozone chamber experiments and were supervised by KS and JC. JC and JRS were responsible for acquisition of funding to support the research and original conception of the overall project. JRS collected tissues for sequencing. DM performed library preparation and sequencing and was supervised by SS. MS and KG directed the data analysis aspects of the research and edited the manuscript. All authors read and approved the final manuscript.

\section{Funding}

This work was primarily supported by the NSF PGRP-OIS-1025974 "Comparative Genomics of Environmental Stress Responses in North American Hardwoods" grant (PI John Carlson). This work was also supported by the USDA National Institute of Food and Federal Appropriations under Project PEN04532 and Accession number 1000326, and by The Louis W. Schatz Center for Tree Molecular Genetics.

\section{Availability of data and materials}

All RNA-Seq data are available in the NCBI Sequence Read Archive database under BioProject accession number PRJNA273270. The reference transcriptome sequences are available on the Hardwood Genomics Project website (https://www.hardwoodgenomics.org/Transcriptome-assembly/1963023).

Ethics approval and consent to participate Not applicable.

\section{Consent for publication}

Not applicable.

\section{Competing interests}

The authors declare that they have no competing interests.

\section{Author details}

${ }^{1}$ The Department of Entomology and Plant Pathology, University of Tennessee, Knoxville, TN 37996, USA. ${ }^{2}$ The Department of Ecosystem Science 
and Management, Pennsylvania State University, University Park, PA 16802, USA. ${ }^{3}$ Department of Biological \& Environmental Sciences, University of West Alabama, Livingston, AL 35470, USA. ${ }^{4}$ Department of Biological Sciences, Notre Dame University, 46556 Notre Dame, IN, France. ${ }^{5}$ Singapore Centre for Environmental Life Sciences Engineering (SCELSE) Nanyang Technological University, Nanyang Avenue 637551, Singapore.

Received: 10 April 2019 Accepted: 31 January 2020

Published online: 14 February 2020

\section{References}

1. Sork VL, Stowe KA, Hochwender C. Evidence for local adaptation in closely adjacent subpopulations of northern red oak (Quercus rubra L.) expressed as resistance to leaf herbivores. The Am Nat. 1993;142(6):928-36.

2. Luppold WG, Bumgardner MS. Examination of lumber price trends for major hardwood species. Wood Fiber Sci. 2007;39(3):404-13.

3. Godfrey RK. Trees, shrubs, and woody vines of northern Florida and adjacent Georgia and Alabama. Athens: University of Georgia Press; 1988.

4. Sander IL. Quercus rubra L. northern red oak. Silvics North Am. 1990;2:727-33.

5. Newell Wohner PJ, Cooper RJ, Greenberg RS, Schweitzer SH. Weather affects diet composition of rusty blackbirds wintering in suburban landscapes. JWildlife Manage. 2016;80(1):91-100.

6. Abrams MD. The postglacial history of oak forests in eastern North America. Oak Forest Ecosystems Ecol. 2002;3445:34-45.

7. Steiner KC. Autumn predation of northern red oak seed crops. In: Gottschalk, Kurt W; Fosbroke, Sandra LC, ed Proceedings, 10th Central Hardwood Forest Conference; 1995 March 5-8; Morgantown, WV: Gen Tech Rep NE-197 Radnor, PA: US Dep Agric, Forest Serv, Northeastern Forest Exp Station 489-494: 1995; 1995.

8. Rodríguez-Correa H, Oyama K, Quesada M, Fuchs EJ, González-Rodríguez A. Contrasting patterns of population history and seed-mediated gene flow in two endemic Costa Rican oak species. J Hered. 2018;1:13.

9. Oyama K, Herrera-Arroyo ML, Rocha-Ramírez V, Benítez-Malvido J, RuizSánchez E, González-Rodríguez A. Gene flow interruption in a recently human-modified landscape: the value of isolated trees for the maintenance of genetic diversity in a Mexican endemic red oak. Forest Ecol Manag. 2017; 390:27-35.

10. Makela M, Michael P, Theriault G, Nkongolo K. High genetic variation among closely related red oak (Quercus rubra) populations in an ecosystem under metal stress: analysis of gene regulation. Genes Genom. 2016;38(10): 967-76.

11. Lind-Riehl J, Gailing O. Fine-scale spatial genetic structure of two red oak species, Quercus rubra and Quercus ellipsoidalis. Plant Syst Evol. 2015;301(6): 1601-12.

12. Alexander LW, Woeste KE. Pyrosequencing of the northern red oak (Quercus rubra L.) chloroplast genome reveals high quality polymorphisms for population management. Tree Genet Genomes. 2014;10(4):803-12.

13. Law JR, Gott JD. Oak mortality in the Missouri Ozarks. In: Proceedings of the Central Hardwood Forest Conference: 1987: University of Tennessee: Knoxville, TN, USA; 1987: 427-436.

14. Heitzman E, Muzika R-M, Kabrick J, Guldin JM. Assessment of oak decline in Missouri, Arkansas, and Oklahoma. In: In: Yaussy, Daniel A; Hix, David M; Long, Robert P; Goebel, P Charles, eds Proceedings, 14th Central Hardwood Forest Conference; 2004 March 16-19; Wooster, OH Gen Tech Rep NE-316 Newtown Square, PA: US Department of Agric, Forest Serv, Northeastern Res Station: 510: 2004; 2004.

15. Crosby MK, Fan Z, Spetich MA, Leininger TD, Fan X. Early indications of drought impacts on forests in the southeastern United States. Forest Chron. 2015;91(4):376-83.

16. Gottardini E, Cristofori A, Pellegrini E, La Porta N, Nali C, Baldi P, Sablok G. Suppression substractive hybridization and NGS reveal differential transcriptome expression profiles in wayfaring tree (Viburnum lantana L.) treated with ozone. Front Plant Sci. 2016;7:713.

17. Rustad L, Campbell J, Dukes JS, Huntington T, Lambert KF, Mohan J, Rodenhouse N. Changing climate, changing forests: the impacts of climate change on forests of the northeastern United States and eastern Canada. Gen Tech Rep. 2012;99:1-48.

18. Gribko LS, Schuler TM, Ford WM. Biotic and abiotic mechanisms in the establishment of northern red oak seedlings: a review. Gen Tech Rep. 2002; 295:18.
19. McLaughlin SB, Nosal M, Wullschleger SD, Sun G. Interactive effects of ozone and climate on tree growth and water use in a southern Appalachian forest in the USA. New Phytol. 2007;174(1):109-24.

20. Skärby L, Troeng E, Boström C-Å. Ozone uptake and effects on transpiration, net photosynthesis, and dark respiration in scots pine. For Sci. 1987;33(3):801-8.

21. Chappelka AH, Samuelson LJ. Ambient ozone effects on forest trees of the eastern United States: a review. New Phytol. 1998;139(1):91-108.

22. Bonello P, Heller W, Sandermann H. Ozone effects on root-disease susceptibility and defence responses in mycorrhizal and non-mycorrhizal seedlings of scots pine (Pinus sylvestris L.). New Phytol. 1993;124(4):653-63.

23. Cannon JRWN. Gypsy moth (Lepidoptera: Lymantriidae) consumption and utilization of northern red oak and white oak foliage exposed to simulated acid rain and ozone. Environ Entomol. 1993;22(3):669-73.

24. Coleman JS, Jones CG. Plant stress and insect performance: cottonwood, ozone and a leaf beetle. Oecologia. 1988;76(1):57-61

25. Fierke M, Kinney D, Salisbury V, Crook D, Stephen F. Development and comparison of intensive and extensive sampling methods and preliminary within-tree population estimates of red oak borer (Coleoptera: Cerambycidae) in the Ozark Mountains of Arkansas. Environ Entomol. 2005; 34(1):184-92.

26. Wright SL, Hall RW, Peacock JW. Effect of simulated insect damage on growth and survival of northern red oak (Quercus rubra L.) seedlings. Environ Entomol. 1989;18(2):235-9.

27. Donley DE. Number, size, and location of red oak borer, Enaphalodes rufulus Haldeman, attack sites on red oaks in Indiana. Proc 3rd Cent Hardwood Forest Conference. 1980;1980:16-7.

28. Lovett GM, Canham CD, Arthur MA, Weathers KC, Fitzhugh RD. Forest ecosystem responses to exotic pests and pathogens in eastern North America. AIBS Bull. 2006;56(5):395-405.

29. Neale DB, Kremer A. Forest tree genomics: growing resources and applications. Nat Rev Genet. 2011;12(2):111.

30. Magalhães AP, Verde N, Reis F, Martins I, Costa D, Lino-Neto T, Castro PH, Tavares RM, Azevedo H. RNA-Seq and gene network analysis uncover activation of an ABA-dependent signalosome during the cork oak root response to drought. Front Plant Sci. 2016;6:1195.

31. Le Provost G, Lesur I, Lalanne C, Da Silva C, Labadie K, Aury JM, Leple JC, Plomion C. Implication of the suberin pathway in adaptation to waterlogging and hypertrophied lenticels formation in pedunculate oak (Quercus robur L.). Tree Physiol. 2016;36(11):1330-42.

32. Gugger PF, Peñaloza-Ramírez JM, Wright JW, Sork VL. Whole-transcriptome response to water stress in a California endemic oak. Quercus lobata Tree Physiol. 2017;37(5):632-44.

33. Schmid-Siegert E, Sarkar N, Iseli C, Calderon S, Gouhier-Darimont C, Chrast J, Cattaneo P, Schütz F, Farinelli L, Pagni M. Low number of fixed somatic mutations in a long-lived oak tree. Nat Plants. 2017;3(12):926.

34. Kurth F, Feldhahn L, Bönn M, Herrmann S, Buscot F, Tarkka MT. Large scale transcriptome analysis reveals interplay between development of forest trees and a beneficial mycorrhiza helper bacterium. BMC Genomics. 2015; 16(1):658.

35. Maboreke HR, Feldhahn L, Bönn M, Tarkka MT, Buscot F, Herrmann S, Menzel R, Ruess L. Transcriptome analysis in oak uncovers a strong impact of endogenous rhythmic growth on the interaction with plant-parasitic nematodes. BMC Genomics. 2016;17(1):627.

36. Pereira-Leal JB, Abreu IA, Alabaça CS, Almeida MH, Almeida P, Almeida T, Amorim Ml, Araújo S, Azevedo H, Badia A. A comprehensive assessment of the transcriptome of cork oak (Quercus suber) through EST sequencing. BMC Genomics. 2014;15(1):371.

37. Usié A, Simões F, Barbosa P, Meireles B, Chaves I, Gonçalves S, Folgado A, Almeida MH, Matos J, Ramos AM. Comprehensive analysis of the cork oak (Quercus suber) transcriptome involved in the regulation of bud sprouting. Forests. 2017;8(12):486.

38. Gugger PF, Cokus SJ, Sork VL. Association of transcriptome-wide sequence variation with climate gradients in valley oak (Quercus lobata). Tree Genet Genomes. 2016;12(2):15.

39. Orendovici-Best T, Skelly JM, Davis DD. Spatial and temporal patterns of ground-level ozone within north-Central Pennsylvania forests. Northeast Nat. 2010:247-60.

40. Comrie AC. A synoptic climatology of rural ozone pollution at three forest sites in Pennsylvania. Atmos Environ. 1994;28(9):1601-14.

41. Sharma YK, Davis KR. Ozone-induced expression of stress-related genes in Arabidopsis thaliana. Plant Physiol. 1994;105(4):1089-96. 
42. Evans NH, McAinsh MR, Hetherington AM, Knight MR. ROS perception in Arabidopsis thaliana: the ozone-induced calcium response. Plant J. 2005; 41(4):615-26.

43. Mahalingam R, Jambunathan N, Gunjan SK, Faustin E, Weng H, Ayoubi P. Analysis of oxidative signalling induced by ozone in Arabidopsis thaliana. Plant Cell Environ. 2006;29(7):1357-71.

44. Denk T, Grimm GW, Manos PS, Deng M, Hipp AL. An updated infrageneric classification of the oaks: review of previous taxonomic schemes and synthesis of evolutionary patterns. In: Oaks Physiological Ecology Exploring the Functional Diversity of Genus Quercus L. New York City: Springer; 2017; 7:13-38.

45. Sork VL, Fitz-Gibbon ST, Puiu D, Crepeau M, Gugger PF, Sherman R, Stevens K, Langley CH, Pellegrini M, Salzberg SL. First draft assembly and annotation of the genome of a California endemic oak Quercus lobata Née (Fagaceae). G3: Genes Genomes Genet. 2016;6(11):3485-95.

46. Plomion C, Aury J-M, Amselem J, Leroy T, Murat F, Duplessis S, Faye S, Francillonne N, Labadie K, Le Provost G. Oak genome reveals facets of long lifespan. Nat Plants. 2018;4(7):440.

47. Ramos AM, Usié A, Barbosa P, Barros PM, Capote T, Chaves I, Simões F Abreu I, Carrasquinho I, Faro C. The draft genome sequence of cork oak. Sci Data. 2018;5:180069.

48. Ernst J, Bar-Joseph Z. STEM: a tool for the analysis of short time series gene expression data. BMC Bioinform. 2006;7(1):191.

49. Lesur I, Bechade A, Lalanne C, Klopp C, Noirot C, Leplé JC, Kremer A, Plomion C, Le Provost G. A unigene set for European beech (Fagus sylvatica L.) and its use to decipher the molecular mechanisms involved in dormancy regulation. Mol Ecol Resour. 2015;15(5):1192-204.

50. Torre S, Tattini M, Brunetti C, Fineschi S, Fini A, Ferrini F, Sebastiani F. RNAseq analysis of Quercus pubescens leaves: de novo transcriptome assembly, annotation and functional markers development. PLoS One. 2014;9(11): e112487.

51. Lane T, Best T, Zembower N, Davitt J, Henry N, Xu Y, Koch J, Liang H, McGraw J, Schuster $\mathrm{S}$. The green ash transcriptome and identification of genes responding to abiotic and biotic stresses. BMC Genomics. 2016;17(1):702.

52. Müller M, Seifert S, Lübbe T, Leuschner C, Finkeldey R. De novo transcriptome assembly and analysis of differential gene expression in response to drought in European beech. PLoS One. 2017;12(9):e0184167.

53. Lulin $H$, Xiao $Y$, Pei $S$, Wen $T$, Shangqin $H$. The first Illumina-based de novo transcriptome sequencing and analysis of safflower flowers. PLoS One. 2012; 7(6):e38653.

54. Xie F, Burklew CE, Yang Y, Liu M, Xiao P, Zhang B, Qiu D. De novo sequencing and a comprehensive analysis of purple sweet potato (Impomoea batatas L.) transcriptome. Planta. 2012;236(1):101-13.

55. Ali M, Li P, She G, Chen D, Wan X, Zhao J. Transcriptome and metabolite analyses reveal the complex metabolic genes involved in volatile terpenoid biosynthesis in garden sage (Salvia officinalis). Sci Rep. 2017;7(1):16074.

56. Sebastiana M, Vieira B, Lino-Neto T, Monteiro F, Figueiredo A, Sousa L, Pais MS, Tavares R, Paulo OS. Oak root response to ectomycorrhizal symbiosis establishment: RNA-Seq derived transcript identification and expression profiling. PLoS One. 2014;9(5):e98376.

57. Yendrek CR, Koester RP, Ainsworth EA. A comparative analysis of transcriptomic, biochemical, and physiological responses to elevated ozone identifies species-specific mechanisms of resilience in legume crops. J Exp Bot. 2015;66(22):7101-12

58. Bussotti F, Desotgiu R, Cascio C, Pollastrini M, Gravano E, Gerosa G, Marzuoli R, Nali C, Lorenzini G, Salvatori E. Ozone stress in woody plants assessed with chlorophyll a fluorescence. A critical reassessment of existing data. Environ Exp Bot. 2011;73:19-30

59. Fernie AR, Carrari F, Sweetlove LJ. Respiratory metabolism: glycolysis, the TCA cycle and mitochondrial electron transport. Curr Opin Plant Biol. 2004; 7(3):254-61.

60. Ludwikow A, Sadowski J. Gene networks in plant ozone stress response and tolerance. J Integr Plant Biol. 2008;50(10):1256-67.

61. Pellegrini E, Francini A, Lorenzini G, Nali C. Ecophysiological and antioxidant traits of Salvia officinalis under ozone stress. Environ Sci Pollut Res. 2015; 22(17):13083-93.

62. Zhang L, Xu B, Wu T, Wen M-X, Fan L-X, Feng Z-Z, Paoletti E. Transcriptomic analysis of Pak Choi under acute ozone exposure revealed regulatory mechanism against ozone stress. BMC Plant Biol. 2017, 17(1):236.

63. Dizengremel P. Effects of ozone on the carbon metabolism of forest trees. Plant Physiol Bioch. 2001;39(9):729-42.
64. Heath R, Taylor G. Physiological processes and plant responses to ozone exposure. In: Forest decline and ozone. Springer; 1997. p. 317-68.

65. Miller JD, Arteca RN, Pell EJ. Senescence-associated gene expression during ozone-induced leaf senescence in Arabidopsis. Plant Physiol. 1999;120(4):1015-24.

66. Gielen B, Löw M, Deckmyn G, Metzger U, Franck F, Heerdt C, Matyssek R, Valcke R, Ceulemans R. Chronic ozone exposure affects leaf senescence of adult beech trees: a chlorophyll fluorescence approach. J Exp Bot. 2006; 58(4):785-95.

67. Sawai S, Saito K. Triterpenoid biosynthesis and engineering in plants. FrontPlant Sci. 2011:2:25.

68. Szakiel A, Pączkowski C, Henry M. Influence of environmental abiotic factors on the content of saponins in plants. Phytochem Rev. 2011;10(4):471-91.

69. Osbourn AE. Preformed antimicrobial compounds and plant defense against fungal attack. Plant Cell. 1996;8(10):1821.

70. Gonzalez-Coloma A, Reina M, Diaz CE, Fraga BM. Santana-Meridas O. Natural product-based biopesticides for insect control in Comprehensive Natural Products. 2013:3:237-68.

71. Loreto F, Schnitzler J-P. Abiotic stresses and induced BVOCs. Trends Plant Sci. 2010;15(3):154-66.

72. Saleem M, Nazir M, Ali MS, Hussain H, Lee YS, Riaz N, Jabbar A. Antimicrobial natural products: an update on future antibiotic drug candidates. Nat Prod Rep. 2010;27(2):238-54

73. Calfapietra C, Wiberley AE, Falbel TG, Linskey AR, Mugnozza GS, Karnosky DF, Loreto F, Sharkey TD. Isoprene synthase expression and protein levels are reduced under elevated $\mathrm{O} 3$ but not under elevated $\mathrm{CO} 2$ (FACE) in field-grown aspen trees. Plant Cell Environ. 2007;30(5):654-61.

74. Gill SS, Tuteja N. Reactive oxygen species and antioxidant machinery in abiotic stress tolerance in crop plants. Plant Physiol Bioch. 2010;48(12):909-30.

75. Møller IM, Jensen PE, Hansson A. Oxidative modifications to cellular components in plants. Annu Rev Plant Biol. 2007;58:459-81.

76. Rejeb I, Pastor V, Mauch-Mani B. Plant responses to simultaneous biotic and abiotic stress: molecular mechanisms. Plants. 2014:3(4):458-75.

77. Atkinson NJ, Urwin PE. The interaction of plant biotic and abiotic stresses: from genes to the field. J Exp Bot. 2012;63(10):3523-43.

78. Toyota M, Spencer D, Sawai-Toyota S, Jiaqi W, Zhang T, Koo AJ, Howe GA Gilroy S. Glutamate triggers long-distance, calcium-based plant defense signaling. Science. 2018;361(6407):1112-5.

79. Eckey-Kaltenbach H, Kiefer E, Grosskopf E, Ernst D, Sandermann H. Differential transcript induction of parsley pathogenesis-related proteins and of a small heat shock protein by ozone and heat shock. Plant Mol Biol. 1997;33(2):343-50

80. Kärenlampi SO, Airaksinen K, Miettinen AT, Kokko HI, Holopainen JK, Kärenlampi LV, Karjalainen RO. Pathogenesis-related proteins in ozoneexposed Norway spruce [Picea abies (karst) L.]. New Phytol. 1994;126(1):81-9.

81. Ernst D, Schraudner M, Langebartels $C$, Sandermann H. Ozone-induced changes of mRNA levels of $\beta-1,3$-glucanase, chitinase and 'pathogenesisrelated'protein 1b in tobacco plants. Plant Mol Biol. 1992;20(4):673-82.

82. Banerjee A, Roychoudhury A. Rice responses and tolerance to elevated ozone: Advances in Rice Research for Abiotic Stress Tolerance. Elsevier; 2019. p. 399-411.

83. Felzer B, Kicklighter D, Melillo J, Wang C, Zhuang Q, Prinn R. Effects of ozone on net primary production and carbon sequestration in the conterminous United States using a biogeochemistry model. Tellus B: Chem Phys Meteorol. 2004;56(3):230-48.

84. Reddy GN, Arteca RN, Dai YR, Flores H, Negm F, Pell E. Changes in ethylene and polyamines in relation to mRNA levels of the large and small subunits of ribulose bisphosphate carboxylase/oxygenase in ozone-stressed potato foliage. Plant Cell Environ. 1993;16(7):819-26.

85. Jolivet $Y$, Bagard M, Cabané M, Vaultier M-N, Gandin A, Afif D, Dizengremel $P$, Le Thiec D. Deciphering the ozone-induced changes in cellular processes: a prerequisite for ozone risk assessment at the tree and forest levels. Ann Forest Sci. 2016;73(4):923-43.

86. Wittig VE, Ainsworth EA, Long SP. To what extent do current and projected increases in surface ozone affect photosynthesis and stomatal conductance of trees? A meta-analytic review of the last 3 decades of experiments. Plant Cell Environ. 2007;30(9):1150-62.

87. Saxe H. Physiological responses of trees to ozone-interactions and mechanisms. Curr T Plant Biol. 2002;3:27-55.

88. Waldeck N, Burkey K, Carter T, Dickey D, Song Q, Taliercio E. RNA-Seq study reveals genetic responses of diverse wild soybean accessions to increased ozone levels. BMC Genomics. 2017;18(1):498. 
89. Feng Z, Kobayashi K. Assessing the impacts of current and future concentrations of surface ozone on crop yield with meta-analysis. Atmos Environ. 2009;43(8):1510-9.

90. Dann MS, Pell EJ. Decline of activity and quantity of ribulose bisphosphate carboxylase/oxygenase and net photosynthesis in ozone-treated potato foliage. Plant Physiol. 1989:91(1):427-32.

91. Reich PB, Amundson RG. Ambient levels of ozone reduce net photosynthesis in tree and crop species. Science. 1985;230(4725):566-70.

92. Samuelson L, Kelly J. Carbon partitioning and allocation in northern red oak seedlings and mature trees in response to ozone. Tree Physiol. 1996;16(10): 853-8.

93. Edwards GS, Wullschleger SD, Kelly JM. Growth and physiology of northern red oak: preliminary comparisons of mature tree and seedling responses to ozone. Environ Pollut. 1994;83(1-2):215-21.

94. Hanson P, Samuelson L, Wullschleger S, Tabberer T, Edwards G. Seasonal patterns of light-saturated photosynthesis and leaf conductance for mature and seedling Quercus rubra L. foliage: differential sensitivity to ozone exposure. Tree Physiol. 1994;14(12):1351-66.

95. Pell E, Temple P, Friend A, Mooney H, Winner W. Compensation as a plant response to ozone and associated stresses: an analysis of ROPIS experiments. J Environ Qual. 1994;23(3):429-36.

96. Xu E, Vaahtera L, Horak H, Hincha DK, Heyer AG, Brosche M. Quantitative trait loci mapping and transcriptome analysis reveal candidate genes regulating the response to ozone in Arabidopsis thaliana. Plant Cell Environ. 2015;38(7):1418-33.

97. Langebartels C, Wohlgemuth H, Kschieschan S, Grün S, Sandermann H. Oxidative burst and cell death in ozone-exposed plants. Plant Physiol Bioch. 2002:40(6-8):567-75.

98. Liu J-J, Sturrock R, Ekramoddoullah AK. The superfamily of thaumatin-like proteins: its origin, evolution, and expression towards biological function. Plant Cell Rep. 2010;29(5):419-36.

99. Tarr PT, Tarling EJ, Bojanic DD, Edwards PA, Baldán Á. Emerging new paradigms for ABCG transporters. Biochimica et Biophysica Acta -Mol Cell Biol Lipids. 2009;1791(7):584-93.

100. Torii KU. Leucine-rich repeat receptor kinases in plants: structure, function, and signal transduction pathways. Int Rev Cytol. 2004;234:1-46.

101. Konar A, Choudhury O, Bullis R, Fiedler L, Kruser JM, Stephens MT, Gailing O, Schlarbaum S, Coggeshall MV, Staton ME. High-quality genetic mapping with ddRADseq in the non-model tree Quercus rubra. BMC Genomics. 2017; 18(1):417.

102. Heck WW, Philbeck RB, Dunning JA. A continuous stirred tank reactor (CSTR) system for exposing plants to gaseous air contaminants. Principles, specificatiions, construction, and operation [Air pollution injuries, beans]. ARS-S-US. Agric Res Serv. 1978;181.

103. Orendovici T, Skelly J, Ferdinand J, Savage J, Sanz M-J, Smith G. Response of native plants of northeastern United States and southern Spain to ozone exposures; determining exposure/response relationships. Environ Pollut. 2003;125(1):31-40.

104. Chang S, Puryear J, Cairney J. A simple and efficient method for isolating RNA from pine trees. Plant Mol Biol Rep. 1993;11(2):113-6.

105. Poinar HN, Schwarz C, Qi J, Shapiro B, MacPhee RD, Buiques B, Tikhonov A, Huson DH, Tomsho LP, Auch A. Metagenomics to paleogenomics: largescale sequencing of mammoth DNA. Science. 2006;311(5759):392-4.

106. Andrews S. FastQC: a quality control tool for high throughput sequence data; 2010.

107. Bolger AM, Lohse M, Usadel B. Trimmomatic: a flexible trimmer for Illumina sequence data. Bioinformatics. 2014:30(15):2114-20.

108. Grabherr MG, Haas BJ, Yassour M, Levin JZ, Thompson DA, Amit I, Adiconis X, Fan L, Raychowdhury R, Zeng Q, et al. Full-length transcriptome assembly from RNA-Seq data without a reference genome. Nat Biotechnol. 2011;29(7):644.

109. Fu L, Niu B, Zhu Z, Wu S, Li W. CD-HIT: accelerated for clustering the nextgeneration sequencing data. Bioinformatics. 2012;28(23):3150-2.

110. Smith-Unna R, Boursnell C, Patro R, Hibberd JM, Kelly S. TransRate: reference-free quality assessment of de novo transcriptome assemblies. Genome Res. 2016

111. Haas BJ, Papanicolaou A, Yassour M, Grabherr M, Blood PD, Bowden J, Couger MB, Eccles D, Li B, Lieber M. De novo transcript sequence reconstruction from $\mathrm{RNA}$-seq using the trinity platform for reference generation and analysis. Nat Protoc. 2013;8(8):1494
112. Simão FA, Waterhouse RM, loannidis P, Kriventseva EV, Zdobnov EM. BUSCO: assessing genome assembly and annotation completeness with single-copy orthologs. Bioinformatics. 2015;31(19):3210-2.

113. Conesa A, Götz S. Blast2GO: a comprehensive suite for functional analysis in plant genomics. Int J Plant Genomics. 2008;2008:12.

114. Altschul SF, Gish W, Miller W, Myers EW, Lipman DJ. Basic local alignment search tool. J Mol Biol. 1990;215(3):403-10.

115. Ashburner M, Ball CA, Blake JA, Botstein D, Butler H, Cherry JM, Davis AP, Dolinski K, Dwight SS, Eppig JT, et al. Gene ontology: tool for the unification of biology. The Gene Ontology Consortium Nat Genet. 2000;25(1):25-9.

116. Ye J, Fang L, Zheng H, Zhang Y, Chen J, Zhang Z, Wang J, Li S, Li R, Bolund $L$, et al. WEGO: a web tool for plotting GO annotations. Nucleic Acids Res. 2006;34(Web Server issue):W293-7.

117. Anders S, Pyl PT, Huber W. HTSeq--a Python framework to work with highthroughput sequencing data. Bioinform. 2015:31(2):166-9.

118. Robinson MD, McCarthy DJ, Smyth GK. edgeR: a bioconductor package for differential expression analysis of digital gene expression data. Bioinform. 2010;26(1):139-40

119. Benjamini $Y$, Hochberg Y. Controlling the false discovery rate: a practical and powerful approach to multiple testing. J Royal Stat Soc: Series B. 1995: 289-300.

120. Oliveros JC. VENNY. An interactive tool for comparing lists with Venn Diagrams. 2007-2015. https://bioinfogp.cnb.csic.es/tools/venny/index.html. Accessed 6 Feb 2020.

121. Tian T, Liu Y, Yan H, You Q, Yi X, Du Z, Xu W, Su Z. agriGO v2.0: a GO analysis toolkit for the agricultural community, 2017 update. Nucleic Acids Res. 2017:45(W1):W122-9.

122. Xie C, Mao X, Huang J, Ding Y, Wu J, Dong S, Kong L, Gao G, Li CY, Wei L. KOBAS 2.0: a web server for annotation and identification of enriched pathways and diseases. Nucleic Acids Res. 2011;39(Web Server issue):W316-22.

123. Langfelder $P$, Horvath S. WGCNA: an R package for weighted correlation network analysis. BMC Bioinform. 2008;9(1):559.

\section{Publisher's Note}

Springer Nature remains neutral with regard to jurisdictional claims in published maps and institutional affiliations.

Ready to submit your research? Choose BMC and benefit from:

- fast, convenient online submission

- thorough peer review by experienced researchers in your field

- rapid publication on acceptance

- support for research data, including large and complex data types

- gold Open Access which fosters wider collaboration and increased citations

- maximum visibility for your research: over $100 \mathrm{M}$ website views per year

At BMC, research is always in progress.

Learn more biomedcentral.com/submissions 